\title{
Impossibly good looks: A pragma-ontological approach to unearthing the latent rhetorical structure of anti-ageing advertising discourse
}

\author{
George Rossolatos \\ University of Kassel \\ Germany \\ e-mail: georgerossolatos123@gmail.com
}

\begin{abstract}
This paper aims at unearthing the appeals, the argumentative schemes and the modes of rhetorical configuration that make up the rhetorical structure of the anti-ageing skin care product category's print advertising discourse. To this end, the pragma-ontological approach is put forward as an offshoot of the pragma-dialectical perspective in rhetorical analysis and criticism. The pragma-ontological approach adds interpretative depth to the overt argumentation structure of anti-ageing products' ads on the grounds of fundamental ontology/existential phenomenology. The analysis points to three levels where the ads' arguments function: an overt level and two covert ones. On the overt level the ads function against the background of mixed ethos/pathos/ logos appeals that buttress an argumentation scheme from values. On a primary covert level, the ads appear to be functioning through an indirect appeal to fear, while resting on an argumentation scheme from consequences. On a secondary covert level, the ads are shown to be appealing indirectly to ontological angst, while manifesting an argumentation scheme per impossibile. The cultural implications for policy-making are highlighted amidst a predicament where anti-ageing claims are attracting heavy criticism.
\end{abstract}

Keywords: rhetorical analysis; critical discourse analysis; anti-ageing advertising; fundamental ontology; existential phenomenology

\section{Introduction: Scope and aims of this study}

This paper unearths different levels of rhetorical structuration in the ad discourse of anti-ageing products. The analysis of a rhetorical structure (not to be confused with RST - rhetorical structure theory) entails addressing three main components, namely rhetorical appeals, schemes of argumentation, and rhetorical figures. To this end, I adopt the pragma-dialectical perspective in rhetorical analysis 
and criticism (Van Eemeren, Houtlosser 2000), fruitfully enriched by critical discourse analytical tools (Fairclough 1995; Van Dijk 2006; Van Leeuwen 2008; Machin, Mayr 2012; Wodak, Meyer 2001). The pragma-dialectical perspective is extended by introducing the pragma-ontological offshoot. The latter adopts the critical mindset of the pragma-dialectical perspective, while informing it with key conceptual constructs from fundamental ontology (Heidegger 2001) and existential phenomenology (Sartre 1992) with a view to demonstrating how the evoked theory attains to offer deeper insights compared to the elicitation techniques that are customarily used in consumer-oriented ad research. This is attained by analysing the rhetorical structure of a corpus of 21 print ads (Appendix 1) ${ }^{1}$ from the antiageing category on three analytical levels, an overt level and two covert ones. Upon scrutinizing the rhetorical structure of the ads successively from overt to covert argumentation and appeals, it turns out that positive mixed appeals are ultimately conditioned by an indirect appeal to fear, itself being conditioned by an appeal to ontological angst. At the same time, the successive substitution of the major conditional premises in the inferential structure of the adopted argumentation schemes results in the transition from an overt argumentation scheme from values, to a covert argumentation scheme from consequences and, ultimately, to an argumentation per impossibile.

Rhetoric and semiotics have been sister disciplines ever since antiquity in multifarious ways and levels of cross-fertilization (Klinkenberg 1990; Nöth 1990; Lotman 2009; Rossolatos 2013c). For Aristotle, argumentation from signs constitutes a key propositional form in the deployment of enthymematic syllogisms (cf. Rossolatos 2013a) which has been carried over to contemporary typologies of argumentation schemes (cf. the argumentation scheme from signs in Walton 2006). According to Greimas (1976), rhetorical figures cut across the entire trajectory of signification, while figurative modes of connectivity are responsible for a text's structuration, as they affect directly the way whereby the isotopic pillars of a text may be construed. The same function of rhetoricity in upholding isotopically (Rossolatos 2013b) the semantic coherence of a textual edifice has been repeatedly stressed by Rastier (1987), Klinkenberg (1990) and Eco (1986), among others.

Although the bulk of theorizing and empirical applications of rhetorical semiotics have been concerned with rhetorical figures and operations (most eminently in Groupe $\mu$ 's treatises; see Rossolatos 2014 for an overview), rather than with argumentation schemes, the application of the latter in critical discourse analysis coheres neatly with the principal tasks of critical semiotic analysis.

1 The corpus of images can be accessed via the journal's electronic issue at http://www.sss. ut.ee/index.php/sss. 
In this respect, attending to modes of argumentative structuration is not a complementary objective for a rhetorical semiotic audience, but a foundational task with regard to modes of tropical configuration. The optimal route consists in producing configurations of schemes with tropes, that is, clusters of tropoi (figures) and arguments (topoi; cf. Casalis 1975; Wilmoth 1982), thus furnishing a comprehensive outlook of the rhetorical structuration of ad texts (Rossolatos 2013e). In fact, as highlighted by Abbott (2006), severing argumentation from considerations pertaining to figures and the overwhelming pre-occupation with typological aspects of tropes was a principal reason for the demise of classical rhetoric.

The contribution of the pragma-dialectical approach to the sub-discipline of rhetorical semiotics, as well as to our understanding of how the discourse of antiageing as a belief system is moulded, may hardly be underplayed. Not only does it constitute a dominant perspective in contemporary rhetorical criticism, but it is well aligned with traditional tasks undertaken by critical semiotic analyses of ad texts (among other discursive forms). Principal among such tasks is the unearthing of the connotative dimension of sign-systems. This task concerns how a set of values shapes up as the signified of a manifest verbal, visual or multimodal discourse and how these values may be read through a cultural axiological lens. For example, Barthes (1977) unearthed the signified (brand value) of freshness by attending to the types of visuals and their syntagmatic arrangement in the famous Panzani pasta ad which he then reduced to various connotative levels based on concurring ideological discourse(s). Therefore, the decoding of meanings that are lurking at a much deeper level is afforded, compared to what might be elucidated by a first-order syntagmatic analysis. In a similar fashion, by attending to the structure of argumentation that sustains figures and that posits the teleological framework that prescribes textually the most plausible interpretation of figures, we are capable of unweaving progressively layers of signification and demonstrating how a belief-system actually underpins seemingly rationally motivated purchase and usage processes. The prevalence of argumentation schemes over figures in the context of analysing (or composing with a view to attaining certain pragmatic effects) social discourses and the redefinition of figures based on their function in argumentative schemes also constituted the key innovation of Perelman's and Olbrecht-Tyteca's New Rhetoric (Klinkenberg 1990).

Pursuant to the above precursory considerations, this paper is structured in the following manner: insofar as this study adopts a cross-disciplinary approach between rhetorical research as conducted within the marketing discipline and as conducted within the discipline of rhetoric, it begins by discussing the relative merits of each approach. Then, it moves onto outlining the objectives and the three research questions that are addressed in the analysis, prior to displaying 
the methodological framework in terms of pragma-dialectics and its pragmaontological offshoot. The description of the creative components of the corpus follows suite, succeeded by a discussion on the rhetorical structure of the corpus on the three analytical levels. The study culminates in pointing out the cultural implications of the pragma-ontological approach for policy-making.

\section{Anti-ageing discourse as a semiotic economy}

Ageing is both a biological and a cultural phenomenon, two aspects that are intimately intertwined insofar as human beings are first and foremost cultural animals. In fact, the cultural aspect of ageing overdetermines the biological dimension and engulfs it in its axiological cryogenics. Slowing down, fending off or masking ageing is a cultural imperative that stems from the beauty ideal. The beauty ideal, although divested in contemporary societal frameworks from its unfathomable Platonic idealist contours where it was born and sublimated to its utmost "celestial" height, retains its canonical status as meta-discursive axiological pillar that permeates social interaction across settings, while overdetermining the affective and libidinal economies. But, above all, the discourse of anti-ageing that is the focalized in this paper, constitutes a sign economy as we are concerned with the differential distribution of signs of anti-ageing versus anti-ageing as such in the respective product category's advertising discourse. This implies that although the object of anti-ageing may not be there or may be there in a piecemeal fashion, the promise of anti-ageing continues to be plausible through the signs that make up the respective discourse. This discourse is edified on postponement and suppression. The discursive signs promise to postpone the advent of the object (ageing) by interpreting anti-ageing as contributing to the attainment of beauty. At the same time, the attainment of beauty is incumbent on the suppression of becoming, and on fleeing from the irreversibility of biological decay. The semiotic economy of the antiageing discourse, thus, is primarily responsible for molding the promise of attaining the cultural ideal of beauty, as will be critically addressed in the following pages.

As expected, given the cultural significance of the anti-ageing discourse in upholding the beauty ideal, the global cosmetics market is particularly lucrative, estimated to reach $\$ 675$ bn in value by 2020 (Raconteur $2016^{2}$ ). The dominant players in the fragmented global cosmetics market and their respective market shares are L'Oréal (13.7\%), Gillette (7.19\%), Nivea (6.17\%), Clinique (5.96\%), Chanel (5.8\%), Neutrogena (4.98\%), Garnier (4.82\%), Pantene (4.8\%), Estée

2 Raconteur 2016. The Beauty Economy. Special Report. Accessed at https://www.raconteur. net/the-beauty-economy-2016 on 13 June 2017. 
Lauder (4.17\%), Dove (4.1\%). From a sub-categories segmentation point of view of the global cosmetics market, skincare has the highest market share (36.1\%), followed by haircare (22.9\%). From a benefits segmentation point of view of the global wellness industry, 'beauty and anti-ageing' constitutes the dominant segment, with a market value of $\$ 999$ bn (2015) (Raconteur 2016). The global anti-ageing products market is projected to increase between 2016 and 2020 at a CAGR of 5.46\%. The key segment growth drivers consist in an ageing population, the proliferation of product offerings for customized needs by leveraging new technologies and ingredients, as well as the pursuit of more effective promotional strategies (Technavio 201633).

\section{Overview of advertising rhetorical research within the marketing and rhetoric disciplines}

According to Killingsworth 2005, 'to appeal' roughly means 'to plead' and it was employed as a translation of the Aristotelian notion of 'pistis' which designates the process of belief-formation. Appeal designates the process of smoothing the communicative waters (Killingsworth 2005) between an author or an orator and an audience by pleading to the categories of ethos, logos and pathos.

Advertising research into rhetorical appeals has been both intensive and extensive, while spanning various disciplines, such as marketing, rhetoric, discourse studies, media and cultural studies. "Advertising appeals can be persuasive by claiming that a brand exemplifies the social norms of a particular group" (O'Shaughnessy, O’Shaughnessy 2004: 65). Within the marketing discipline, a wide gamut of appeals have been scrutinized by advertising researchers over the years, such as emotional in general (Tanner 2006; Wicks et al. 2009), disgust (Dens et al. 2008), threat (Dickinson, Holmes 2008; Dickinson-Delaporte, Holmes 2011; Charry, Demoulin 2012), sex (Richmond, Hartman 1982; Maciejewski 2004; Putrevu 2008), fear (Brooker 1981; Henthorne et al.; Latour et al. 1996), humour (Cline, Kellaris 2007), hard versus soft sell (Okazaki et al. 2010), value-expressive versus utilitarian (Johar, Sirgy 1991), guilt (Chang 2011, 2012).

The main differences between how advertising appeals are customarily approached and analysed within the discipline of rhetoric and within the discipline of marketing consist in focusing differentially on aspects of the overall persuasion process. Within the marketing discipline advertising research focuses largely on

3 Technavio 2016. Anti-ageing products - Market drivers and forecasts. Special Report. Accessed at https://www.businesswire.com/news/home/20161201005046/en/Anti-agingProducts-\%E2\%80\%93-Market-Drivers-Forecasts-Technavio on 18 July 2017. 
the outcomes of appeals in terms of consumer behaviour variables, such as attitude towards an ad, attitude towards a brand, intention to buy, shifts in likeability (cf. Hornik et al. 2017). Occasionally such outcomes are also examined from the standpoint of precedents, as well as of pre-/post-exposure response shifts or as moderating (interim) factors in the persuasion process. Advertising messages are usually presented to consumers in the form of stimuli such as slogans, the body copy of print ads, key visuals (cf. Armstrong 2010; Goddard 1998), either as individual cues or combined. Additionally, a special branch of ad-related research focuses on tropes and schemes and their effects on distinctive consumer groups (cf. McQuarrie, Phillips 2008; Rossolatos 2013c; Belk 2017). However, an analysis alongside the formal rhetorical structure of ads and the adopted argumentation strategies is hardly ever involved, let alone comprehensive approaches that explore in tandem formal aspects of rhetorical structure, that is argumentation schemes, appeals and configuration in terms of schemes and tropes. The same holds for the disciplinary orientation of skin-care-advertising-related studies published in the discourse analytic stream (e.g. Coupland 2009; Kaur et al. 2013; Ellison 2014). On the other hand, ad-appeals-related studies within the rhetorical discipline usually do not involve primary consumer research, but an extrapolation of the likely pragmatic effects of ad messages from a formal analysis of appeals as manifested by the rhetorical structure and argumentative orientation of ads.

\section{The objectives and research questions of this study}

This study is largely situated in the formal analytical camp while aiming at elucidating the rhetorical structure of ad messages in the anti-ageing skin care category, with an occasional emphasis on the tropical constitution of ad texts. The study of the structure and the effects of advertising discourse within both disciplinary frameworks (marketing and rhetoric) has its relative merits and in many respects the focal areas of each approach are complementary. This study adopts a cross-disciplinary approach in the scrutiny of the rhetorical structure of skin care ads. This cross-disciplinary orientation consists in a full-blown analysis of the rhetorical structure of the concerned print ads, against the background of the ad cue types that are customarily researched in marketing, namely slogans, body-copy, key visual(s), pack-shots.

Although primary consumer research is not involved in this study, an attempt is made at generating crucial consumer insights by drawing on Heideggerian ontology and Sartrean existential phenomenology. The adoption of such a philosophical framework for unearthing the latent structure of skin care ads 
has multiple benefits compared to direct consumer questioning or to indirect elicitation methods that are used in ad research and in appeals-related research in general (see, for example, Ruiter et al. 2001; Ruiter et al. 2014).

Firstly, fundamental ontology (Heidegger 2001) sought to furnish fundamental structures of human existence while refraining from reducing philosophy to psychologism. This implies that the psychological perspectives (largely of an egopsychological orientation) adopted in marketing studies are not exhaustive as to the explanatory status of certain variables, but constrained by disciplinary and paradigmatic assumptions (e.g. in motivation theory that all consumer actions are goal-oriented and stem from subjective goal-setting which does not suffice from an ontological point of view as a fundamental presupposition in accounting for human action).

Secondly, the beliefs imbued to consumers by means of rhetorical appeals and arguments follow largely an indirect route to persuasion. Rhetorical analysis and critical discourse analysis are well-equipped for demonstrating the pathways of this indirect route. The evoked ontological conceptual framework is capable of multiplying the referential frameworks where ad claims operate, over and above the "reasons" that emerge through consumer elicitation techniques. As will be shown in due course, although overtly the skin care ads that make up the corpus of this study are predicated on positive claims that render them plausible, once examined from an ontological point of view two additional covert levels emerge.

Thirdly, both existential phenomenological perspectives comprise and converge on an existential mood or state-of-being that is called 'fleeing' by Heidegger and 'self-deception' by Sartre, as will be explained shortly. On the one hand, this stateof-being is crucial for demonstrating the second covert rhetorical structure in the ensuing rhetorical analysis, while on the other hand it is related at a fundamental ontological level to a being's life project, rather than being reducible to a psychological state as response to a situated stimulus.

Based on the above considerations, three main research questions are posited in this study:

(i) What appeals and argumentation schemes are manifestly used in the ad corpus?

(ii) Are there indirect appeals and schemes in the ad corpus?

(iii) If yes, how does the employment of the ontological interpretive ground aid in unearthing the latent meaning of anti-ageing ads?

Prior to outlining the methodological framework adopted in this study, it is prudent to provide an overview of the existential phenomenological concepts that are utilized in the propounded pragma-ontological approach. 


\section{Outline of Heidegger's and Sartre's existential phenomenological concepts employed in the pragma- ontological approach to rhetorical criticism}

Central to the existential analytic offered by Heidegger in Being and Time (2001) is the structure of care that designates the plenum of Dasein's involvements in the world: "The decisive characteristics in our relation to the world as such, which includes ourselves as our ultimate point of reference, is conditioned by the care that allows us to treat everything as part of our project in the largest sense of the word" (Ridling 2001: 161). "Within this "project" we make of ourselves, everything has its meaning and thereby its Being. The design is, as the term suggests, directed into the future: we project ourselves into an anticipated future as the ultimate aim of our endeavors" (Ridling 2001: 162). Therefore, caring for oneself is manifested as being telically oriented towards one's potentiality-for-Being, as pursuing one's potential in a life project. At this juncture Heidegger introduces the meaning of Beingtowards-death as one's ownmost potentiality-for-Being. Heidegger is clear that Death in the context of fundamental ontology does not concern biological death, but an existential structure of Dasein, as the horizon that conditions teleologically the life project of Dasein (also see Carel 2006).

In contradistinction to fear that is bound up with a determinate object as causal agent in the face of which Dasein experiences the state-of-mind of fear, beingtowards-death is correlated, according to Heidegger, with anxiety. This ontological angst is attributed to the radical indeterminacy of its object, that is death. Although determinate goals partake of an ontological horizon wherein a life project is accomplished and where fear of non-accomplishment manifests itself, anxiety is produced by the possibility of annihilating the horizon altogether. "Death is the possibility of the absolute impossibility of Dasein” (Heidegger 2001: 294).

Ontological angst is more dreadful than fear. This underlying threat that is experienced by Dasein for as long as it is does not manifest itself as a state-of-mind in the face of a determinate object, but as what Heidegger calls 'fleeing in the face of death'. Despite the cryptic character of this designation, it may be unpacked if we consider its operation as underlying Dasein's involvements in-the-world. Fleeing in the face of death is not a state-of-mind that Dasein can escape. In short, Dasein cannot not flee in the face of death as for as long as it is, death is the only certainty of Dasein amidst potentialities-for-Being. Fleeing in the face of death is experienced beneath the attainment of concrete potentialities in an ontological horizon. Fleshing out a potentiality in one's worldly involvements presupposes by definition fleeing from the annihilation of the horizon wherein potentialities materialize. This is not tantamount to exercizing one's free will, that is, opting out 
from fleeing, as that would entail simply the attainment of death as certainty. It is possible, yet in state-of-mind that is called by Heidegger (2001: 300) "evasive concealment in the face of death".

This evasive concealment has been identified by Sartre with self-deception or bad faith ('mauvaise fois'):

Sartre's concept of 'Bad Faith' is sometimes treated as a psychological discovery and illustrated with examples such as obsession, resentment, irony, role playing, self-deception and so on. Such a psychological assessment, however, is liable to overlook the phenomenological 'logic' which underpins this discovery and which follows from the very definition of consciousness as a Nothingness. The law of being of the For-itself is to be what it is not and to not be what it is. Sartre begins by identifying the specifically negative attitude he has in mind and distinguishing it from falsehood. An obvious analogy to bad faith would be that of the lie. The trouble with this analogy is that the liar is aware of the very truth which he conceals from those to whom he tells his lies. But bad faith involves lying to oneself: 'what changes everything is the fact that in bad faith it is from myself that I am hiding the truth' (p. 49). (Macann 1993: 122)

\section{Methodological framework}

In this section the methodological framework that is adopted in this study is laid out, in line with the three analytical levels that were mentioned in the introduction, that is one overt and two covert rhetorical levels. The pragma-dialectical rhetorical perspective that permeates the analysis is exposed in Section 6.1, followed by its proposed offshoot, that is, the pragma-ontological approach in Section 6.2.

In terms of sampling method, purposive sampling has been adopted in this study by drawing on a corpus of 21 print advertisements (Appendix 1) from the key brand players in the skin care category, that is Clinique (manufactured by Estee Lauder), Dermitage, Dove (by Unilever), Estée Lauder, Lancôme, L'Oréal, Olay (by Procter \& Gamble), Nivea (by Beiersdorf), Neutrogena (by Johnson \& Johnson), Revlon, Shiseido. The ad selection criteria consist in inclusiveness as regards the dominant brand players in the anti-ageing segment of the skin care category, their relevance to the overarching anti-ageing theme, and their recency in terms of the respective brands'/sub-brands' launch timing. All ads are in English and were aired in English-speaking markets (UK/US) between 2010-2017. They were sourced from internet ad banks that allow for free access. In terms of analysis methods, the interpretive process did not follow a bottom-up procedure of thematic discovery, but was geared towards examining the rhetorical structure of ads that already revolve around the anti-ageing theme, with a view to identifying a dominant 
pattern in terms of appeals, argumentation and figures (as well as comment on variations, if any).

\subsection{The pragma-dialectical perspective in rhetorical analysis}

"In pragma-dialectics, argumentation is viewed as a phenomenon of verbal communication; it is studied as a mode of discourse characterized by the use of language for resolving a dispute" (Van Eemeren, Houtlosser 2000: 293). The pragma-dialectical approach to argumentation is intent on controlling discourse against logical fallacies, to reconstruct implicit, opaque speech acts and hidden premises and to examine the defensibility of the claims raised by interlocutors in a conversational predicament (Van Rees 2013).

Insofar as here we are not concerned with conversational pragmatics between situated interlocutors, but with print advertising or with one-to-many communications, the analysis concerns the examination of the above areas in the face of the verbo-visual discourse at hand. Thus, the first methodological prong of this study rests with applying the pragma-dialectical approach to the corpus of print ads from the skin-care category in order to (i) reconstruct and interpret the employed discourse with a view to elucidating what pragmatic effects are intended by the advertisers; (ii) unearth hidden premises and conditionals employed in the print ads' verbal and/or visual expressive cues in order to check the defensibility of the argumentation; (iii) analyse the involved argumentation schemes in terms of premises, conclusions and inferential strategies (Walton 1996: 303; Walton et al. 2008). These three tasks of rhetorical analysis are integral to the pragmadialectical perspective, they are applicable to all three research questions and display similarities with critical discourse analytical methods (Fairclough 1995; Machin, Mayr 2012; Reisigl 2014; Van Dijk 2006; Van Leeuwen 2008; Wodak, Meyer 2001). These similarities consist in that both pragma-dialectics and CDA are mutually geared towards unearthing latent and suppressed meanings behind manifest discourse, as well as identifying critical and intentional omissions in manifest discourse. CDA is additionally incumbent on identifying power relations that are operative in the process of discourse formation (Wodak, Meyer 2001). Thus, CDA and especially the rhetorical prong of CDA, will be used in tandem with rhetorical analysis and criticism. 


\subsection{Complementing pragma-dialectics with the pragma-ontological perspective}

The ontological opening up of the interpretive scope of the involved ads alongside the ontological/existential phenomenological territories that were outlined earlier is intent on identifying covert argumentation strategies as per research questions (2) and (3). The pragma-ontological perspective, as conceived and operationalized in this paper, endorses the fundamental tenet of pragma-dialectics that all persuasive communication is geared towards accomplishing pragmatic effects. However, it digs below the surface of manifest claims by discussing how arguments reflect the evoked conceptual constructs from the Heideggerian fundamental-ontological (Heidegger 2001) and the Sartrean existential-phenomenological (Sartre 1992) perspectives that are posited here as interpretive platform. As will be shown, there are significant benefits to be reaped from the adoption of this offshoot, as regards (i) understanding and appreciating that although on the surface ad claims appear to be positive, eventually they are negative; (ii) although on the surface ad claims appear to be conducive to the undertaking of goal-oriented actions, this goaldirectedness is possible only in a self-deceptive mode, as explained earlier; (iii) there are enthemematic conditionals beneath the stated premises; (iv) identifying gaps in the inferential chain of the argumentation structure.

\section{The creative structure of the print ads in the corpus}

This section presents a systematic description of the creative structure of the print ads that are featured in this study (Appendix 1), alongside the verbo-visual types customarily addressed in print advertising research, namely (i) slogans; (ii) bodycopy; (iii) pack-shot; (iv) key visual(s).

As regards (i), slogans may be categorized in three types, namely consumer benefits (e.g. Clinique Youth Surge: Age suspended and time interrupted), consumer actions (L'Oréal Revitalift: Fight 15 signs of Ageing), product functions (Clinique: 3 -step skin-care). Consumer actions are usually manifested in the imperative mode of a fighting posture. In this portrayal, ageing and its signs are posited anthropomorphically as enemies, thus transferring responsibility for thwarting ageing from the product to the consumer (cf. Coupland 2009). The other two types are manifested mostly in the declarative mode and less often in the interrogative mode ("How much time off do you want?"). The semantic content of the slogans that appear in the declarative mode concerns mostly consumer benefits (e.g. "There is another way to see fewer wrinkles") and occasionally commonly accepted topoi (e.g. "Beauty is a statement"). 
As regards (ii), the body-copy consists of the familiar pattern 'problem/ consumer benefit' and its (re)solution (in terms of buying/using the product) by dint of the function/effects of the product, that is anti-ageing. In the context of this specific advertising discourse, anti-wrinkle, anti-lines, firmness and the rest, signs of ageing are semantically subordinate (Snoeck Henkemans 2000) to and inclusive within the conceptual scope of anti-ageing. The order whereby the structural elements of the body-copy are presented varies by ad, as has also been noted in the extant literature (Ringrow 2016: 34). The order of argumentation will be further elaborated rhetorically in the ensuing sections. In terms of lexical selection, product effectiveness claims are often couched in hyperbolically accentuated (Machin, Mayr 2012) adverbial and adjectival post and pre-modifiers, such as “astonishingly even, dramatically refined". Adjectives are occasionally ordered paratactically in asyndeton figurative mode for additional emphasis.

The substantiation of product effectiveness (reason-to-believe or warrant in Toulmin's [2003] terms) consists in patented technologies and active ingredients. "The use of 'scientific' language is especially prevalent in anti-ageing skincare, where it aims to imbue the products with a sense of authenticity and perhaps a guarantee of effectiveness" (Ringrow 2016: 82). Of course, the extent to which the "scientific" evidence provided in skin-care advertising has attained to effectively substantiate the offered claims about consumer benefits constitutes a massive battleground with institutional contesters such as the Federal Trade Commission" ${ }^{4}$ Repeatedly voiced arguments about the insufficiency of anti-ageing "scientific evidence" have imperilled the very sustainability of anti-ageing claims.

As regards (iii), the bulk of the corpus features a single product that is the advertised brand. On the occasion of featuring more than one product, these belong to the same sub-brand, but are of a different and in some instances complementary type, as is the case of Olay Total Effect where the brand includes a duo pack (scrub cleanser and moisturizer).

As regards (iv), the majority of the featured ads portray a single female face in close-up or chest-upwards mode, shot from various angles. Faces are mostly inexpressive or feature a discrete smile in order to avoid withdrawing consumer attention from the skin and towards the meaning of the expressive posture. In instances where more than one models are featured, they concern the main message communicated by the slogan, as in the case of Nivea Advanced Wrinkle Reducer where the two models' actions reflect the slogan "touch and be touched".

$4 \quad$ Federal Trade Commission 2014. "FTC to L'Oréal: Scientific claims need proof that's more than just skin deep" was accessed at https://www.ftc.gov/news-events/blogs/businessblog/2014/06/ftc-loreal-scientific-claims-need-proof-thats-more-just-skin on 27 July 2017. 
Bar-charts with clinical tests results are occasionally featured in the ads, largely positioned close to the body-copy where the "scientific" evidence about the products' effectiveness is provided. Visual metaphors are scarcely included, as in the case of Clinique/youth surge night that features the visual of a purple flower inside an ice-cube on top of the packshot. This visual conveys the slogan "Age suspended and time interrupted" in metaphorical terms (flower = youth; ice-cube = preservation/extension of youth). Finally, endorsers (e.g. Elle Macpherson in Nivea age defying) are occasionally encountered in this corpus, a brand image transfer strategy that is standardly adopted in the wider beauty sector ad discourse. It is also worth noting that the rhetorical visual strategy of forming a vector among visual elements as a cohesive and latent co-ordination device is adopted in Estée Lauder Enlighten where a diagonally shaped visual alliteration (or accolorance, as tagged in Rossolatos 2013d) that rests on the blue colour transpierces the model's eyes, the visual of a butterfly and the pack-shot.

\section{Discussion of findings}

\section{1. (RQ1) What appeals, argumentation schemes and rhetorical figures are manifestly used in the ad corpus?}

\subsubsection{Mixed appeals (logos, pathos, ethos)}

The skin-care ad discourse comprises mixed appeals in the majority of instances, with the exception of ads that do not feature a body-copy (e.g. Dove pro-age). The body-copy in combination with the slogan constitute the textual ground whereupon appeals perform their function in supporting and enabling the plausibility of the argumentation schemes. Appeals to emotion function through sensorially orientated and occasionally hyperbolically accentuated adjectives and adverbs pertaining to skin care, such as "cushiony soft, astonishingly even, dramatically refined" (Lancôme Genifique), "for timeless [...] skin" (Shiseido Ultimune). Emotive appeals lay the foundations for a "positive sensory experience" (Ringrow 2016) that is rendered concrete by appeals to logos, mainly in the form of explicitly formulated causal relations between youthful skin (and its para-synonymic derivatives as shown in the previous section) and the unique ingredients of skin care brands, such as Revlon anti-ageing make-up's declarative statement: "New Revlon age defying with DNA ADVANTAGE is a full coverage makeup that does more than simply cover up the signs of ageing". DNA Advantage, a so-called marketing ingredient or unique formula contained in the brand, is the warrant backing the claim that signs of ageing are not simply covered up, 
but disappear. Of course, as repeatedly argued by Walton, in such rhetorical instances we are not concerned with formal logical proofs and conclusions based on necessary premises, but on culturally contingent topoi (Zompetti 2006) whose proofs partake of informal logic and of the probative value of premises based on the instrumental rationality (Van Leeuwen 2008) of discursive communities (Van Dijk 2006). Thus, the appeal at hand is logical only on the grounds of a recognized topos that the maintenance of a youthful skin is a valid cultural value. Finally, ethotic appeals concern statements that evoke either the "character" of the skin care product category, its mission and values, or wider topoi that are assumed to be sustaining the ethos of this consumer group. The former type resonates in Olay Eyes' slogan "Our eyes should show emotion and not our age", while the latter in the topos "Beauty is a statement" (Nivea Visage), a reformulation of "beauty is in the eye of the beholder".

\subsubsection{The overt argumentation scheme: Argumentation from values (common topoi)}

The overt argumentation scheme that permeates the body-copy of the ads in the anti-ageing segment is argumentation from values (Walton et al. 2008). Notice that argumentation schemes are not necessarily mutually exclusive, and that more than one schemes may be identified in a single ad. For example, a significant portion of this corpus lays overt claims to fighting the signs of ageing, which clearly constitutes an argumentation scheme from signs (Walton 2006). However, the aim here is to identify the most pertinent scheme while assuming as vantage point the character of the major premise that sustains the entire argumentative structure. In these terms, the major premise that underlies the entire corpus consists in the value or recognized topos that anti-ageing or the maintenance of a youthful skin is a positive goal, worthy of undertaking the actions required for attaining it. Broadly speaking, five premises or sets of premises may be identified in the overt argumentation scheme from values in the skin care corpus: (i) major premise 1 (topos or cultural value; cf. Zagar 2009) and conditional that buttresses and sets in motion the argumentative chain: anti-ageing is a valid goal; (ii) major premise 2 as consumer benefit or more concrete goals based on product-specific USPs, (e.g. anti-wrinkle, fights facial lines, spots etc.); (iii) minor premise 1 (elaboration of product function/effectiveness with regard to major premise 2); (iv) minor premise 2 (consumer action to be undertaken in order to bring about major premise 2); (v) warrant (substantiation of the product's ability to perform the stated function). 
According to Walton et al. (2008: 321), an argumentation scheme from values has two forms:

Variant 1: Positive Value.

Premise 1: Value V is positive as judged by agent A (judgment value).

Premise 2: The fact that value $\mathrm{V}$ is positive affects the interpretation and therefore

the evaluation of goal $\mathrm{G}$ of agent $\mathrm{A}$ (if value $\mathrm{V}$ is good, it supports commitment to goal C).

Conclusion: $\mathrm{V}$ is a reason for retaining commitment to goal $\mathrm{G}$.

Variant 2: Negative Value (my note: cf. section 8.2, G. R.).

Premise 1: Value $\mathrm{V}$ is negative as judged by agent $\mathrm{A}$ (judgment value ).

Premise 2: The fact that value $V$ is negative affects the interpretation and therefore

the evaluation of goal $\mathrm{G}$ of agent $\mathrm{A}$ (if value $\mathrm{V}$ is bad, it goes against commitment to goal $G$ ).

Conclusion: $\mathrm{V}$ is a reason for retracting commitment to goal $\mathrm{G}$.

As mentioned earlier, the order whereby arguments appear in the body-copy varies. However, upon reconstruction the same structure appears to be valid for the majority of ads. Below follows an example of how this argumentation scheme is applied to the skin care category (with reference to Revlon's age defying ad):

Slogan: Revlon age defying with DNA ADVANTAGE (heading).

Discover a revolutionary anti-ageing makeup that thinks like an anti-ageing moisturizer (sub-heading).

Body-copy:

New Revlon age defying with DNA ADVANTAGE is a full coverage makeup that does more than simply cover up the signs of ageing.

Its powerful skincare ingredients and SPF 20 help protect your skin's DNA, your most important defense against the signs of ageing.

Lines and wrinkles visibly diminish for a look that's practically flawless.

$96 \%$ of women saw younger skin in 2 weeks

\section{Argumentation structure of Revlon age defying makeup}

Major premise 1 (topos or cultural value as conditional statement):

Striving for anti-ageing is a valid topos. 
Major premise 2 (consumer benefits):

Lines and wrinkles visibly diminish for a look that's practically flawless; important defense against the signs of ageing.

Minor premise 1 (product function/effectiveness): powerful skincare ingredients and SPF 20 help protect your skin's DNA, your most important defense against the signs of ageing.

Minor premise 2 (consumer action to be undertaken in order to bring about major premise 2): Discover a revolutionary anti-ageing makeup.

Warrant: With DNA ADVANTAGE; 96\% of women saw younger skin in 2 weeks.

\subsubsection{Rhetorical figures}

Although less visually than verbally, the skin care category's ad discourse is tropically intensive. On a visual level, we encounter visual metaphors and visual alliteration, as explained in the previous section. Additionally, we encounter visual antithesis in the case of Neutrogena ("I'm 58... But Look Like I'm 38!"). On a verbal level, anthropomorphism is evident where claims of "fighting" against ageing are raised that posit "ageing" as an enemy against whom consumers must undertake immediate actions (L'Oréal Revitalift, Lancôme Primordiale), or where the product performs human processes: "revolutionary anti-ageing makeup that thinks" (Revlon age defying). Adjectival and adverbial hyperboles abound, as shown in the previous section, also giving rise to the figure of expletion. Asyndeton allows for greater communicative impact of the stringed adjectives. Anaphora (the repetition of the same word in two successive sentences, e.g. fight... fight), alliteration (faceforward) and rhyme (deny...defy) enhance the force of the utterance while functioning as cohesive devices.

\section{2. (RQ2) Are there indirect appeals and schemes in the ad corpus?}

\subsubsection{Indirect appeal to fear}

As shown in the previous section, the skin care products' ad discourse contains mixed appeals. Pathemic appeals on the discursive surface are conveyed through positive statements that are valorized as such through a cohort of adjectival and adverbial pre and post-modifiers. However, if we attend more narrowly to the hierarchical order of the semantic structure of this ad discourse, we may gauge that skin care and anti-ageing are not goals in themselves, but subordinate to the attainment of beauty as the ultimate telos of cosmetic practices. The beauty ideal in fact conditions the validity of the cultural topos of anti-ageing. The difference 
is that whereas skin care discourse may be credibly invested with emotive appeals as an interim stage in the attainment of a beauty ideal, beauty as such constitutes a regulative ideal, and, hence, is essentially negative.

Skin care products are always already in proximity to the regulative ideal, but never in absolute overlap with it (as such an imbrication would entail that their effects would no longer be needed). Therefore, for as long as skin care products are used, the beauty ideal that hovers over them as ultimate conditional and raison dêtre remains unattainable. This urges us to lay claim to a latent or indirect fear appeal that stems from the unattainability of the beauty ideal and that conditions the overtly positive emotive appeals.

Skin care products' use is fuelled by the fear of non-attaining the beauty ideal, a paradoxical fear given that this unattainability is a condition sine qua non for the perpetuation of the use of skincare products. "Fear appeal is recognized as a distinctive type of argumentation by empirical researchers, who see it as a kind of argument used to threaten a target audience with a fearful outcome (most typically that outcome is the likelihood of death) in order to get the audience to adopt a recommended response." (Walton 1996: 304). Product benefits, subsequently, are predicated of inverted and sublimated fear appeals.

\subsubsection{Indirect argumentation from consequences}

"Fear appeal arguments do appear to have a structure, as a species of argumentation from consequences, that does involve normative requirements under which they may be used correctly (appropriately), or not, to meet these requirements" (Walton 2000: 21). Walton (2000) further contends that in some cases argumentation from fear is akin to an indirect speech act as a discursive implicature that underlies a positive statement. Indirect or covert fear appeals differ from overt fear appeals that feature manifest signs of threats associated with the advertised topics, such as health (e.g. tobacco advertising, AIDS), transportation (e.g. drunk driving), war (e.g. war on terror).

More concretely, in our case, this standpoint suggests that the positively valorized statements that make up the inferential structure of the argument from values, as presented in the previous section, are in fact underpinned by a negatively valorized major premise as conditional statement behind the manifest conditional statement. This conditional statement is "non-attaining the beauty ideal is fearsome", followed by the already posited major premise in the previous section "striving for anti-ageing is a valid topos". The negative conditional statement, according to Walton (2000) is evinced formally as a message from P (product) to 
$\mathrm{R}$ (recipient): (CS) If you (R) do not bring about $\mathrm{A}$ (action as use of anti-ageing products), then $\mathrm{D}$ (non-attainment of the beauty ideal) will occur. The respective argumentation scheme in this case is an argument from consequences and its inferential structure (Walton 2000) as follows:

$\mathrm{D}$ is very bad for you.

Therefore, you ought to stop $\mathrm{D}$ if possible.

But the only way for you to stop D is to bring about A.

Therefore, you ought to bring about A.

(where $\mathrm{D}=$ non-attainment of the beauty ideal, $\mathrm{A}=$ use of anti-ageing products)

or, you should use anti-ageing products in fear of the negative consequence of not attaining the beauty ideal if you do not do so.

Now, the qualifying difference that infuses this argumentation form with additional complications is that the object of fear, i.e. not attaining the regulative beauty ideal, not only conditions negatively the consequence of the inferential structure (i.e. the need for using anti-ageing products), but is by definition unattainable, as otherwise the use of anti-ageing products would no longer be necessary. This paradoxical relationship between the conditional statement and the consequence opens up a new vista of indirect argumentation that may be elucidated if we attend to the pragma-ontological perspective's premises as will be shown in the ensuing section.

But in the meantime, let us recapitulate the arguments put forward thus far and stretch the inferential chain in order to yield a more expansive picture of why the beauty ideal ultimately may not be attained by the use of anti-ageing products, this time round not by recourse to the discourse's latent principia, but to additional empirical complicating factors.

The incidence of the indirect fear appeal resulted in the inversion of the valorization of the overt argumentation scheme from values (see Section 7.1.2). The outcome of this inversion was the replacement of anti-ageing as major premise with the hidden enthymeme (Dyck 2002; Slade 2002) of the beauty ideal as overarching cultural topos. This transition as contextual requirement (Levi 1985) of the inferential structure of the argument is rendered palatable if we consider that skin care is not valorized per se, but because it contributes to the attainment of the beauty ideal. The relationship between the beauty ideal and anti-ageing may thus be portrayed in the following argumentation scheme from consequences, "as a chaining together of a sequence of sub-inferences" (Walton 1996: 308): 
$\mathrm{G}$ is a goal for a.

a thinks that bringing about $\mathrm{A}$ is a means to bring about $\mathrm{G}$.

Therefore, a concludes that bringing about $\mathrm{A}$ is a practically reasonable course of action. (Walton 1996: 308)

In our case $(G)$ is equivalent to the beauty ideal and (A) to anti-ageing. Although the beauty ideal is not mentioned explicitly in all skin care ads, it is presupposed as a major premise in the inferential chain. This premise functions as a hidden conditional syllogism or as an enthymeme (cf. Rossolatos 2013a) in terms of a dominant topos concerning the importance of the cultural value of seeking the attainment of beauty. Otherwise, that is in the absence of the conditioning function of the beauty ideal, caring for one's skin in a standalone fashion would not make sense.

Two major issues emerge at this juncture. The first concerns the extent to which the means (application of skin care products) does afford to bring about the penultimate consequence (anti-ageing) as a discursively articulated conditio sine qua non for the attainment of the ultimate consequence that is the beauty ideal. In particular, this issue is located at the sub-inferential level from action to interim consequence, i.e. anti-ageing, and concerns the false equation of anti-ageing with a symptom or sign of anti-ageing or of a young-looking face as sign of anti-ageing with anti-ageing in toto. This precludes any other bodily symptoms in other parts of the body that might suggest otherwise.

The second issue concerns the extent to which the symptoms of facial antiageing are capable in themselves of attaining the beauty ideal. Insofar as a beauty ideal does not concern solely facial features, but also other body parts, their potential equation is hardly plausible. It is a false metonymy that conflates the part with the whole. What allows for the plausibility of these two interim inferences, namely (i) that anti-ageing is a consequence of effective skin care and (ii) the attainment of a beauty ideal is the consequence of facial anti-ageing, is the incidence of a belief structure that is evinced as fallacious practical reasoning.

This belief structure is evinced in consumers' decision-making processes as a replacement of relations of contingency and probability with relations of causality between the syllogisms that constitute the beginning and the end of the two interim inferential pairs. More concretely, as the replacement of the premise "the probability of attaining anti-ageing is, among other body parts and quasidetermininig factors, contingent on the application of skin-care products" with the premise "the attainment of anti-ageing is causally dependent on the application of skin care products", and the same ceteris paribus for the second inferential pair. That is, the replacement of relations of contingency with relations of causality 
has been enabled by the suppression of other quasi-determining factors that are responsible for ageing (e.g. nutrition) and other body parts that may manifest symptoms of ageing, even if such symptoms are absent from the facial body-part. In addition, it is not at all clear from the ad texts what will happen if a consumer discontinues applying these products or replaces one brand with another along the way. Indeed, the ad text treats the process as if it is enacted in a sterilized lab where the interactions between consumption and consequence are enacted in the absence of any other organic or environmental influences. However, in actuality, "skin ageing is a complex biological process influenced by the combination of endogenous or intrinsic (genetics, cellular metabolism, hormone and metabolic processes) and exogenous or extrinsic (chronic light exposure, pollution, ionizing radiation, chemicals, toxins) factors" (Ganceviciene et al. 2012: 308). The "lab-like" discursive encapsulation of the process by the ad discourse amounts to reducing the argument from consequences to a make-believe scheme and a case of fallacious practical reasoning. This is precisely the point where the elucidating potential of direct consumer feedback as regards consumer satisfaction from using skin care products comes to a halt and where ontological insights may contribute to gaining access to pre-empirical existential structures that enable the formation of such beliefs.

\section{3. (RQ3) If yes, how does the employment of the ontological interpretive ground aid in unearthing the latent meaning of the skin-care ads?}

\subsubsection{Indirect argumentation scheme per impossibile}

From a fundamental ontological point of view (Heidegger 2001), the above illustrated viciously circular (Betz 2005) and paradoxical relationship between the impossibility of attaining the regulative beauty ideal and the use of anti-ageing products, a relationship that is indirectly manifested as fearsome, is undergirded by the existential structure of being-towards-death in relationship to a Dasein's worldly involvements, a relationship that gives rise to irreducible ontological angst.

The vantage point for unravelling the implications of this analogical relationship consists in examining how angst conditions ontologically the ontic manifestation of fear ("Ontological refers to the internal structures which underlie and constitute the being of a being as its conditions of possibility. Ontic means those actions which are externally observable, which are made possible by the ontological structures" [Demske 1970: 17]). 
As was shown in Section 5, fear presupposes a determinate and identifiable threat. Hence, it is of an ontic dimension. Angst is ontologically oriented as its object is indeterminate. Angst is driven by the impossibility of attaining the whatness of postponement through postponement, that is death. Its indeterminate object conditions teleologically Dasein as being-towards-death, a towardness that constitutes Dasein's ontological horizon as potentiality-for-Being. The ontological relationship between being-towards-death and angst is inscribed in ontic terms (i.e. as a worldly involvement) as the postponement of attaining the beauty ideal through the use of anti-ageing products that postpone the advent of ageing and hence bring about the beauty ideal. This contradiction in terms constitutes the paradoxical structure of attaining the beauty ideal through the use of anti-ageing products.

This paradoxical relationship points to a state-of-mind that is more primordial than fear, and this is ontological angst. If the paradoxical relationship was simply attributable to fear, then the object of fear would be by definition determinate, and hence its non-attainment would be tantamount to a probability as error. However, this probability in the context of the indeterminate object of angst is certain. Thus, although the beauty ideal appears on the surface to be attainable through the use of anti-ageing products, and hence of an ontic dimension, the proof for its nonattainability suggests that it functions ontologically as an antonomasia of beingtowards-death (or as being-towards-the beauty ideal). If this is so, then angst is the requisite state-of-mind. Therefore, on a second covert level of argumentation the ad discourse of skin care products is not premised simply on an indirect fear appeal, but on ontological angst. By implication, and given the inferential structure of the argument from consequences, angst takes the place of fear in the conditioning major premise (i.e. "non-attainment of the beauty ideal is angst-ridden"). However, and this is the crux or the qualifying difference between covert argumentation levels 1 and 2, the consequence here is evinced as a paradoxically impossible task, accommodated under the scheme of an argumentum per impossibile. Thus, the inferential structure of the argument from consequences that was adopted in the previous section, ultimately boils down to the following, from an argumentum per impossibile point of view:

\section{Argument from consequences}

"G is a goal for a.

a thinks that bringing about $\mathrm{A}$ is a means to bring about $\mathrm{G}$.

Therefore, a concludes that bringing about $\mathrm{A}$ is a practically reasonable course of action." (Walton 1996: 308)

(where $(G)$ is equivalent to the beauty ideal and (A) to anti-ageing) 


\begin{abstract}
Argument per impossibile
$\mathrm{G}$ is an impossible goal for $\mathrm{a}$.

a believes that bringing about $\mathrm{A}$ is a means to bring about $\mathrm{G}$.

Therefore, a concludes that bringing about $\mathrm{A}$ is a practically reasonable course of action.
\end{abstract}

The difference between the two schemes consists in the substitution of modality, from a rational (a) to a belief one (b). As shown in Section 5, the formation of the belief that being-towards-death as horizon of possibilities may be resolved through worldly involvements in ontic terms is the outcome of a state of mind that is called by Heidegger (2001:300) "evasive concealment in the face of death", also identified by Sartre with self-deception or bad faith ('mauvaise fois'). Anti-ageing products, on this second covert level, do not postpone or conceal anti-ageing as a precondition for attaining the beauty ideal, but the impossibility of attaining the beauty ideal, regardless of whether anti-ageing products are used or not. The certainty of this non-attainment is postponed in the multiple acts of concealment that constitute a permeating ethos of self-deception. At the same time, and this is the concluding remark on the viciously circular and impossible relationship between anti-ageing products use and the attainment of the beauty ideal, the by definition latent defeasibility that sustains the goal of the cultural practice of caring for one's skin is responsible for its perpetuation as angst-ridden flight in the face of death.

\title{
9. Conclusions
}

This study transpires at a critical juncture where skin care products' positioning on the grounds of anti-ageing claims is constantly under fire, especially from institutional authorities. Vestiges of alternative slogans and positioning strategies were included in this corpus, such as Dove's pro-age and Nivea's advance wrinkle reducer ('Touch and be touched'). The question, though, remains, if anti-age claims that rest with indirect fear appeals on a secondary level, as shown in this paper, were removed, would this discourse be redeemed from the angst-laden indirect appeals that stem from the ultimate dependence of this discourse on the impossible attainment of a beauty ideal? This ideal has been evoked as a source of legitimacy in the employment of subordinate claims, such as the anti-ageing ones, for centuries and in fact constitutes the overarching representational terrain that engulfs the essence of skin care products' use. On the one hand, following the Dove route is a disruptive option as an alternative discourse within the dominant discourse (Fairclough 1995) presided by the beauty ideal. However, 
it is questionable whether its effectiveness would be the same if it had surfaced relationally against the background of another dominant discourse. On the other hand, the Nivea route is not defining of a specific category, but it might as well be part of various product/category discourses.

These issues are particularly important not just for brand marketers, but also for policy makers, as what is at stake is not just a set of brand specific claims, but timehallowed cultural ideals, such as the beauty ideal rooted in an ocularcentric culture (Sandywell 1999), the hegemony of vision (Levin 1993) and the sovereign gaze (Merleau-Ponty 1968). In this predicament, the discursive construal of the face on the grounds of the beauty ideal is a necessary condition for the maintenance of the socialized gaze. The offered pragma-ontological approach to rhetorical analysis and criticism offered in this study was found to be quite potent in unearthing latent premises of an overt rhetorical structure that concern fundamental aspects of existence as culturally organized. If fundamental aspects of a cultural order such as being-towards-the beauty ideal (as a deflected manifestation of the fundamental existential structure of being-towards-death) are disrupted, then an existential void is bound to emerge that will take time to heal in the event that a sufficiently binding antonomasia is not discovered. 
Impossibly good looks

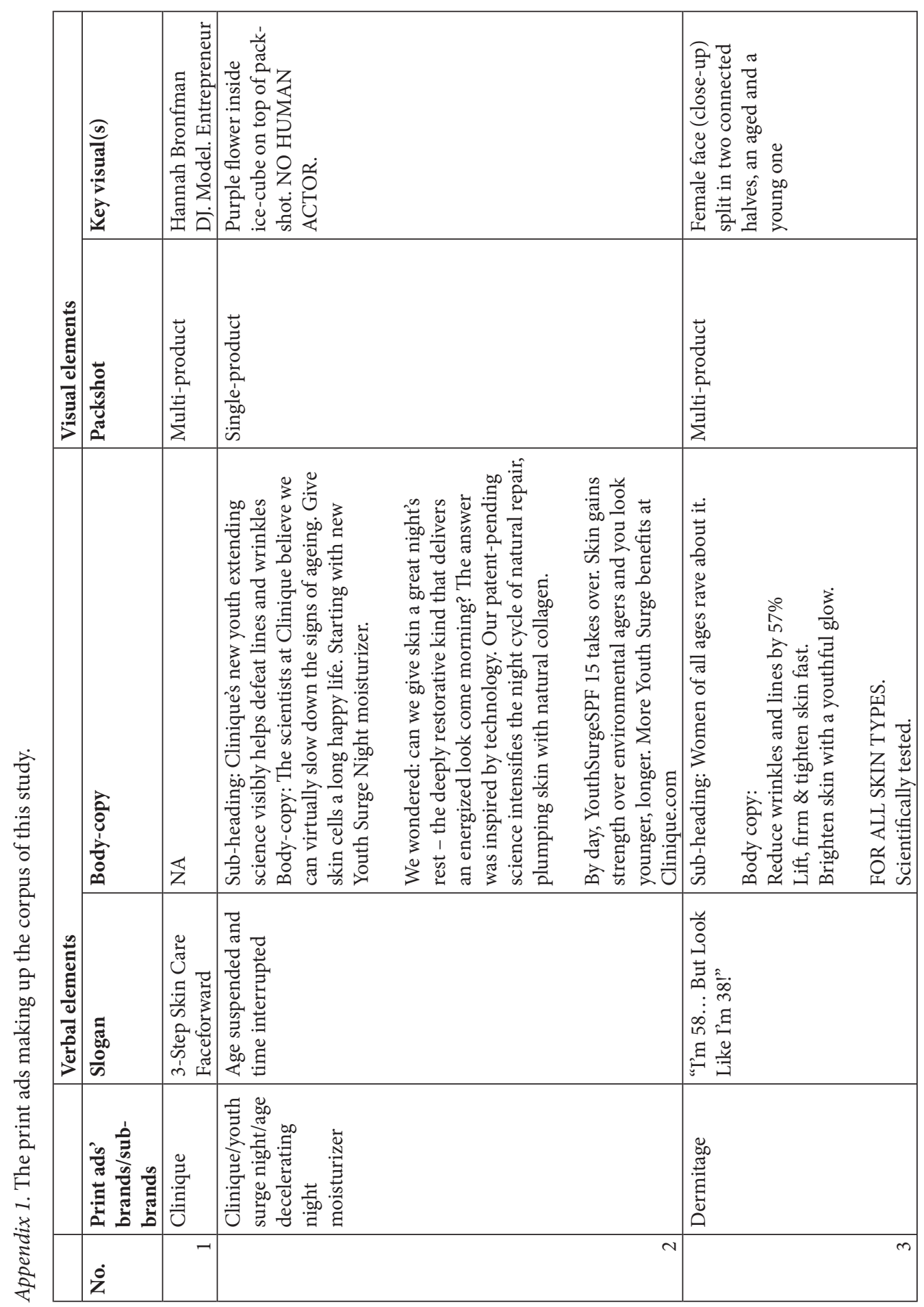


240 George Rossolatos

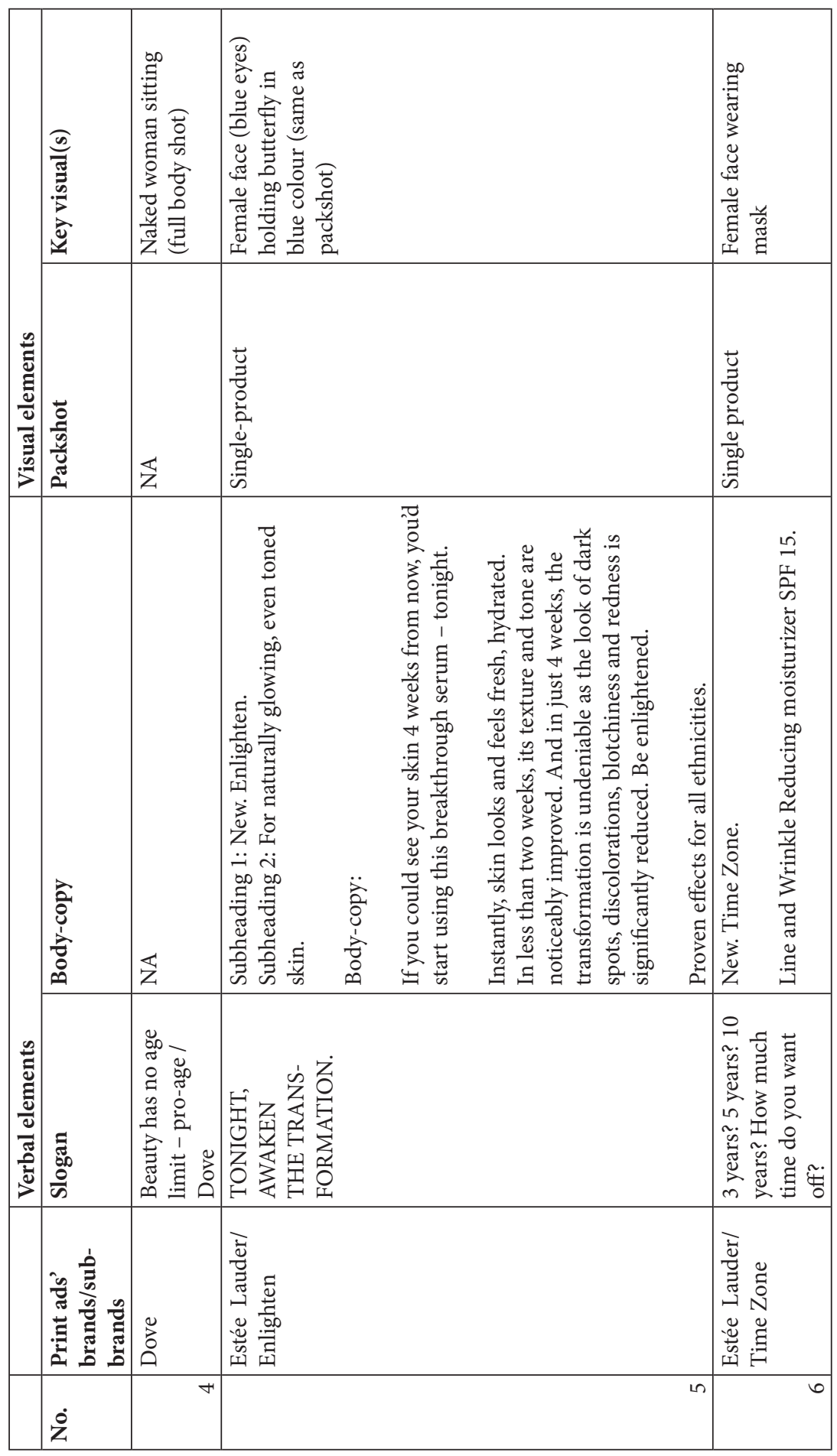




\begin{tabular}{|c|c|c|c|c|c|c|c|}
\hline \multirow[b]{2}{*}{ 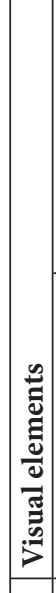 } & 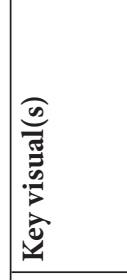 & 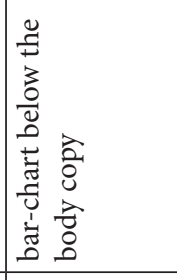 & & & & & \\
\hline & 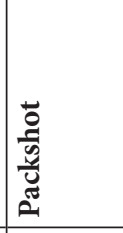 & 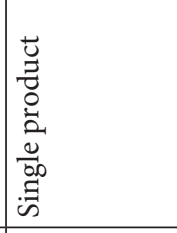 & & & & & \\
\hline \multirow{4}{*}{ 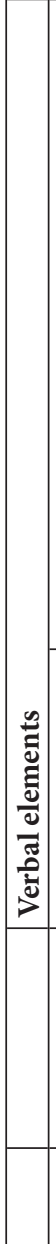 } & 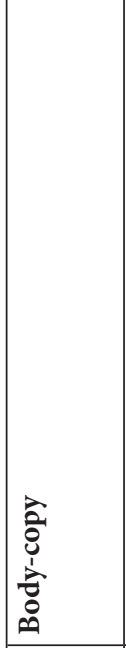 & 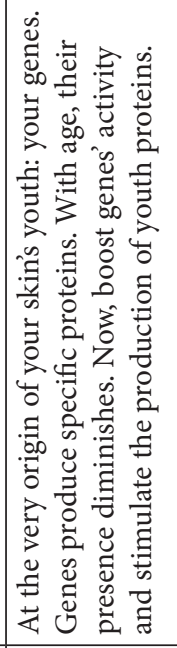 & 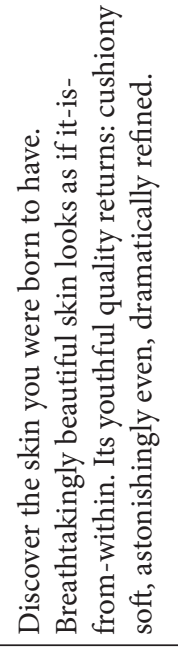 & 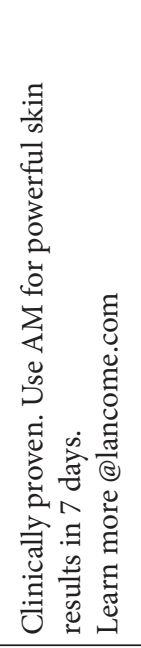 & 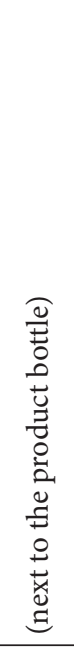 & 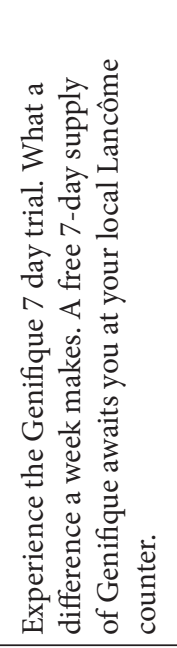 & 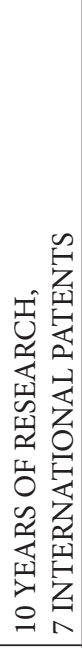 \\
\hline & 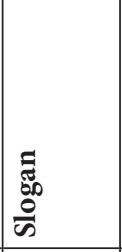 & 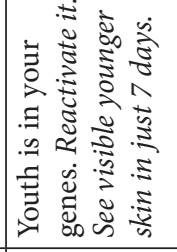 & & & & & \\
\hline & 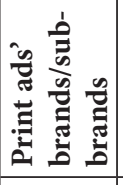 & 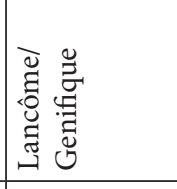 & & & & & \\
\hline & $\dot{z}$ & & & & & & \\
\hline
\end{tabular}


242 George Rossolatos

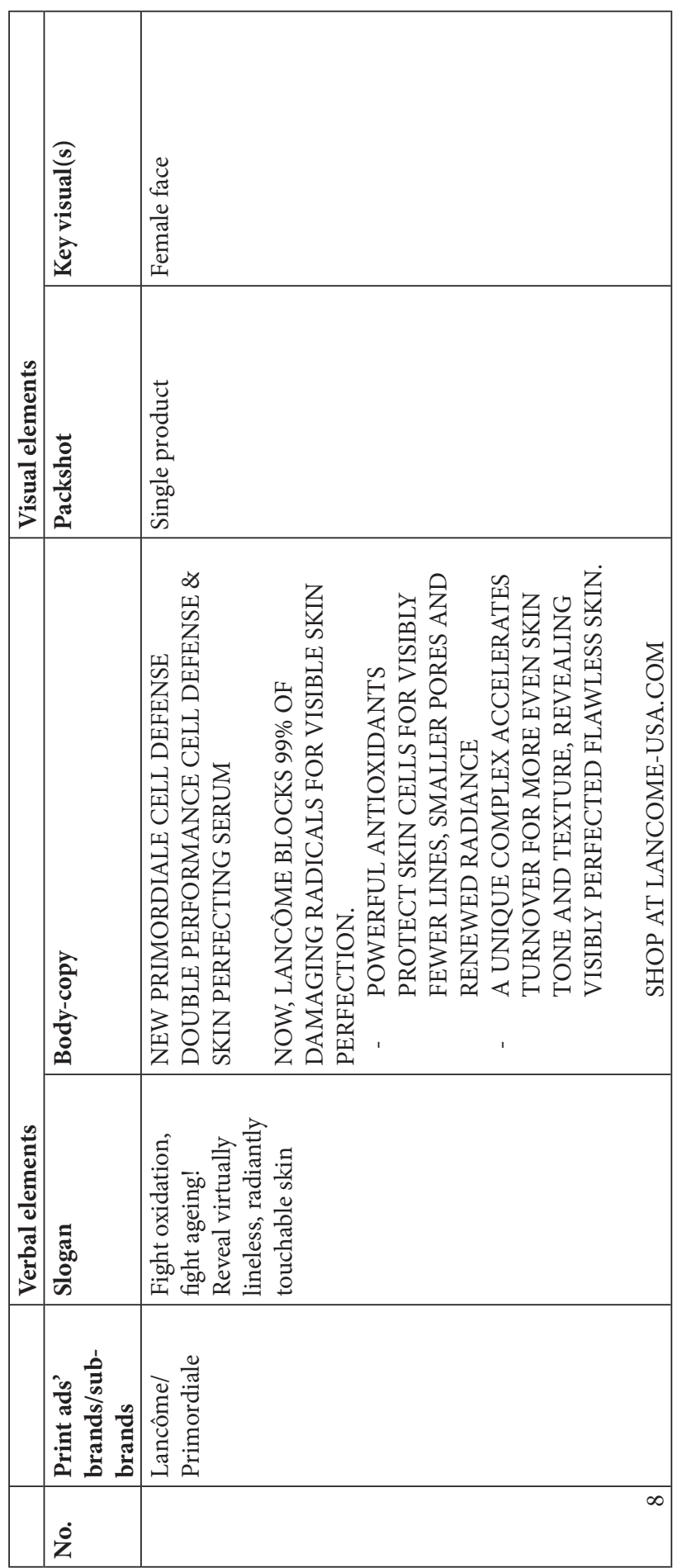




\begin{tabular}{|c|c|c|c|c|c|}
\hline \multirow[b]{2}{*}{ 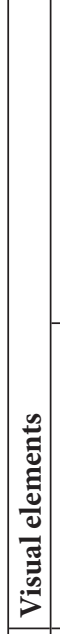 } & 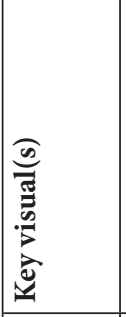 & 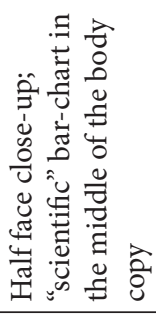 & & & \\
\hline & 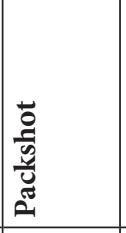 & 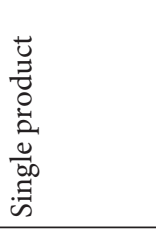 & & & \\
\hline \multirow{4}{*}{ 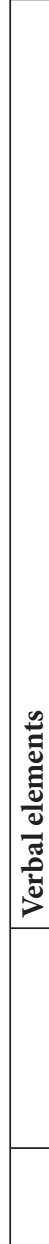 } & 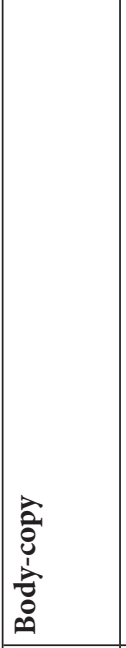 & 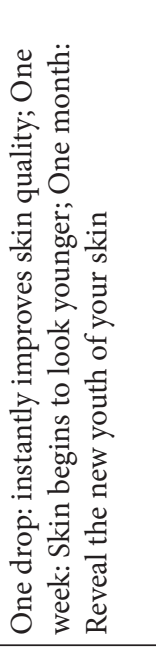 & 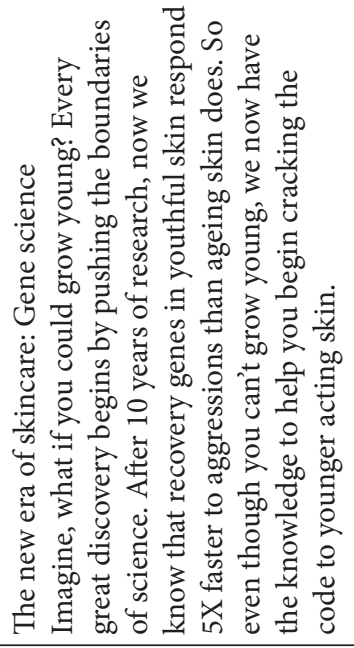 & 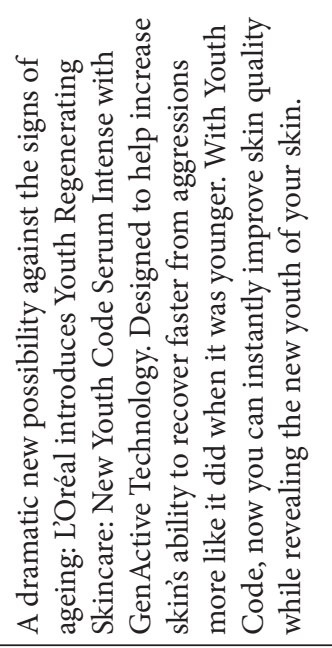 & 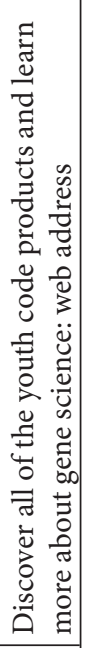 \\
\hline & 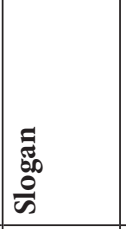 & \multicolumn{4}{|l|}{ 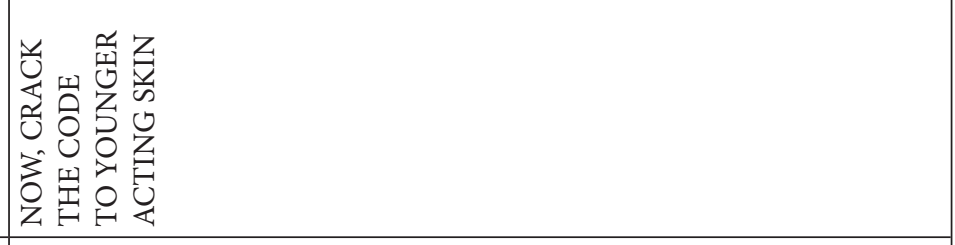 } \\
\hline & 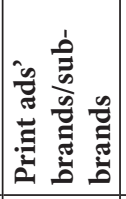 & 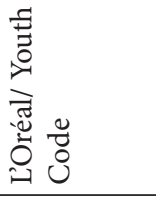 & & & \\
\hline & $\dot{z}$ & & & & \\
\hline
\end{tabular}


244 George Rossolatos

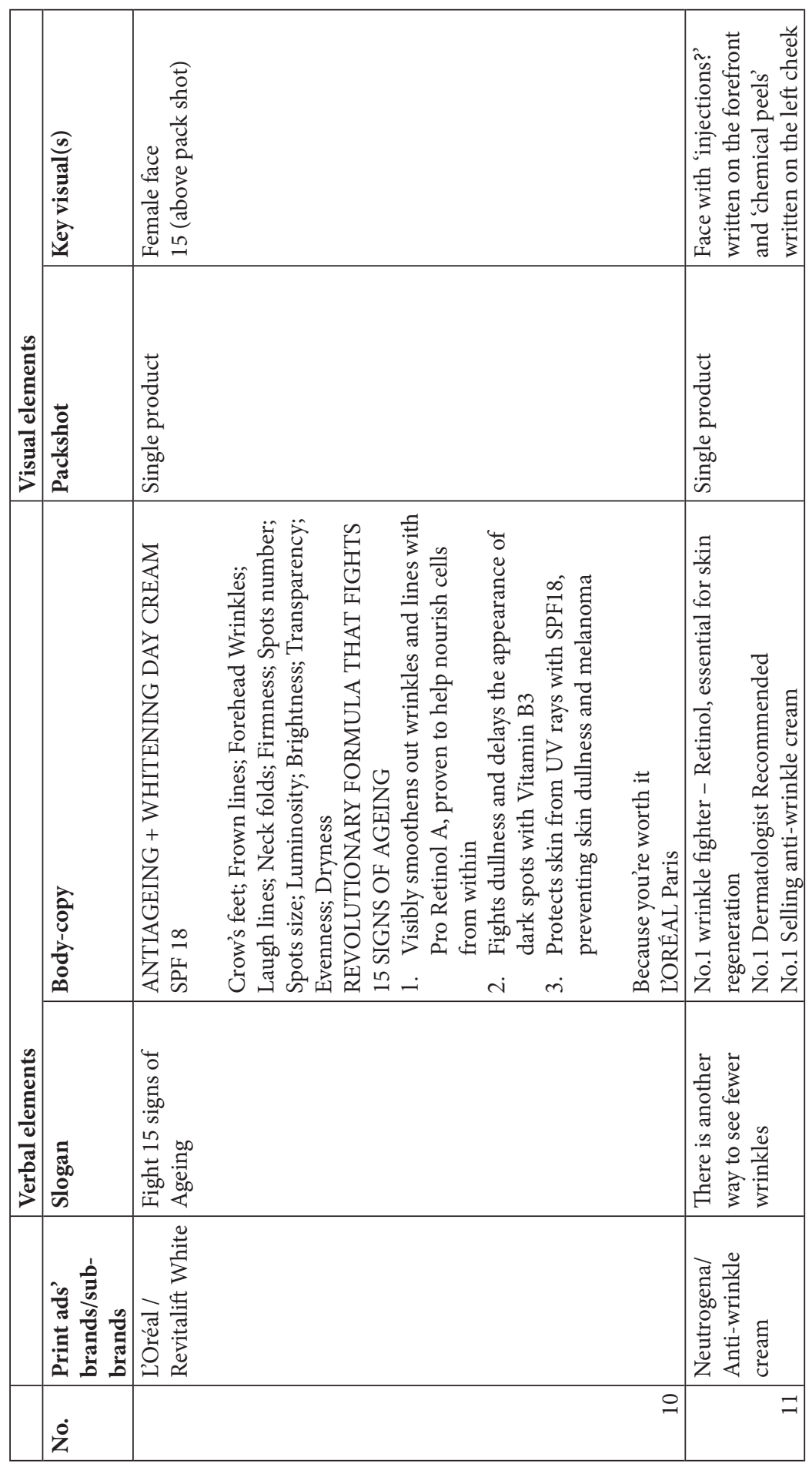




\begin{tabular}{|c|c|c|c|c|c|c|c|}
\hline \multirow[b]{2}{*}{ 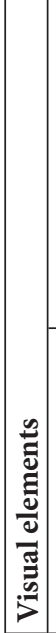 } & 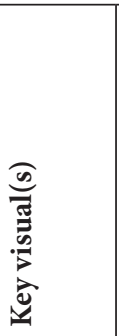 & \multicolumn{2}{|l|}{ 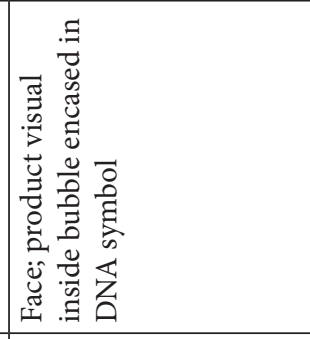 } & \multicolumn{3}{|l|}{ 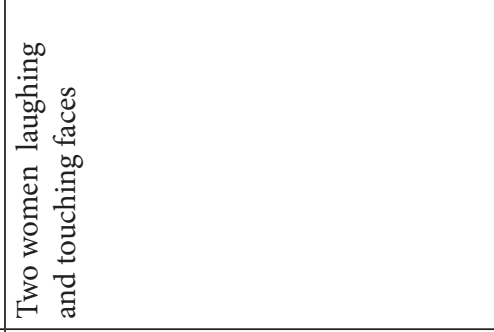 } & 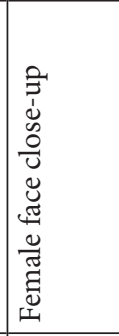 \\
\hline & & 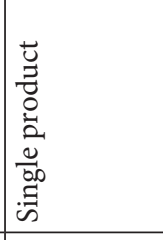 & & 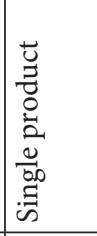 & & & 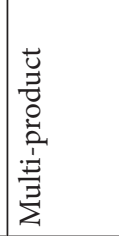 \\
\hline & 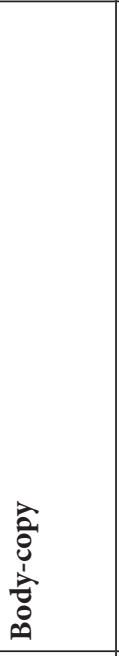 & 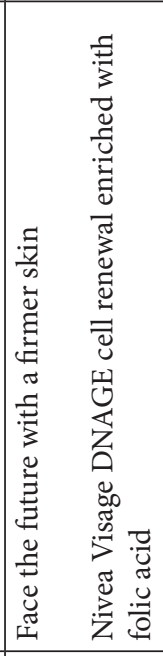 & 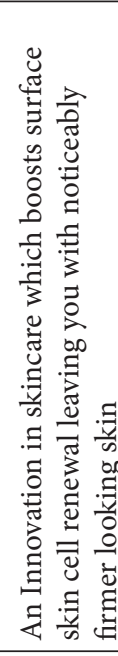 & 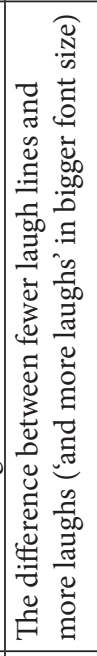 & 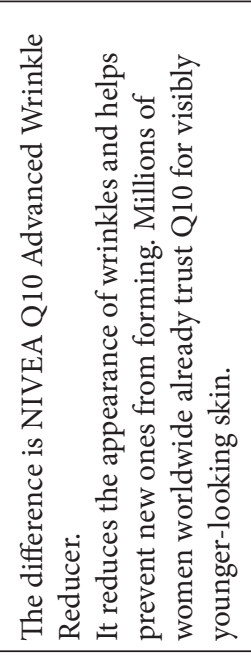 & 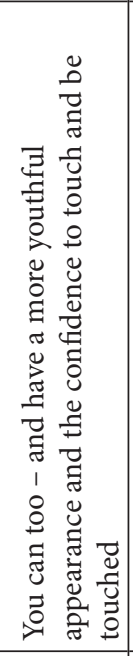 & \begin{tabular}{|l}
$\mid$ \\
Z \\
\end{tabular} \\
\hline 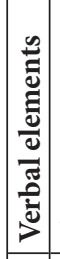 & 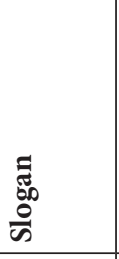 & 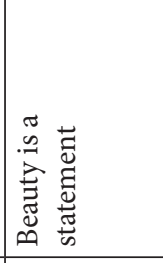 & & 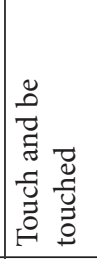 & & & 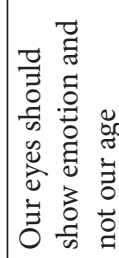 \\
\hline & 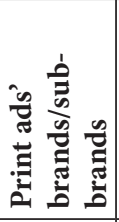 & 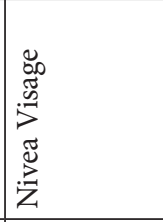 & & 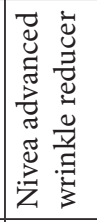 & & & 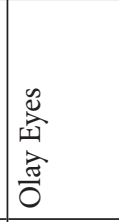 \\
\hline & $\dot{z}$ & & $\simeq$ & & & $\Rightarrow$ & \pm \\
\hline
\end{tabular}


246 George Rossolatos

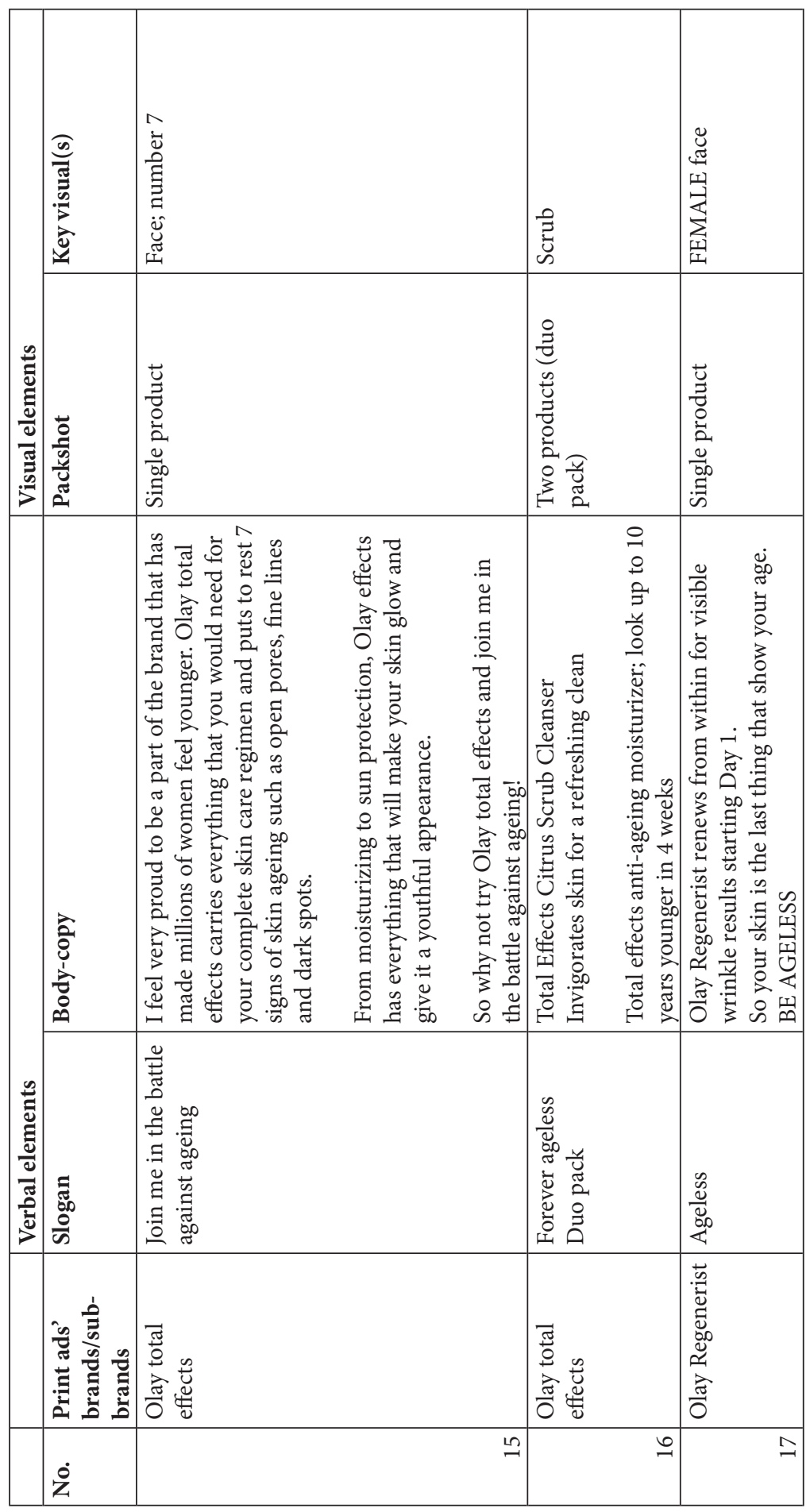




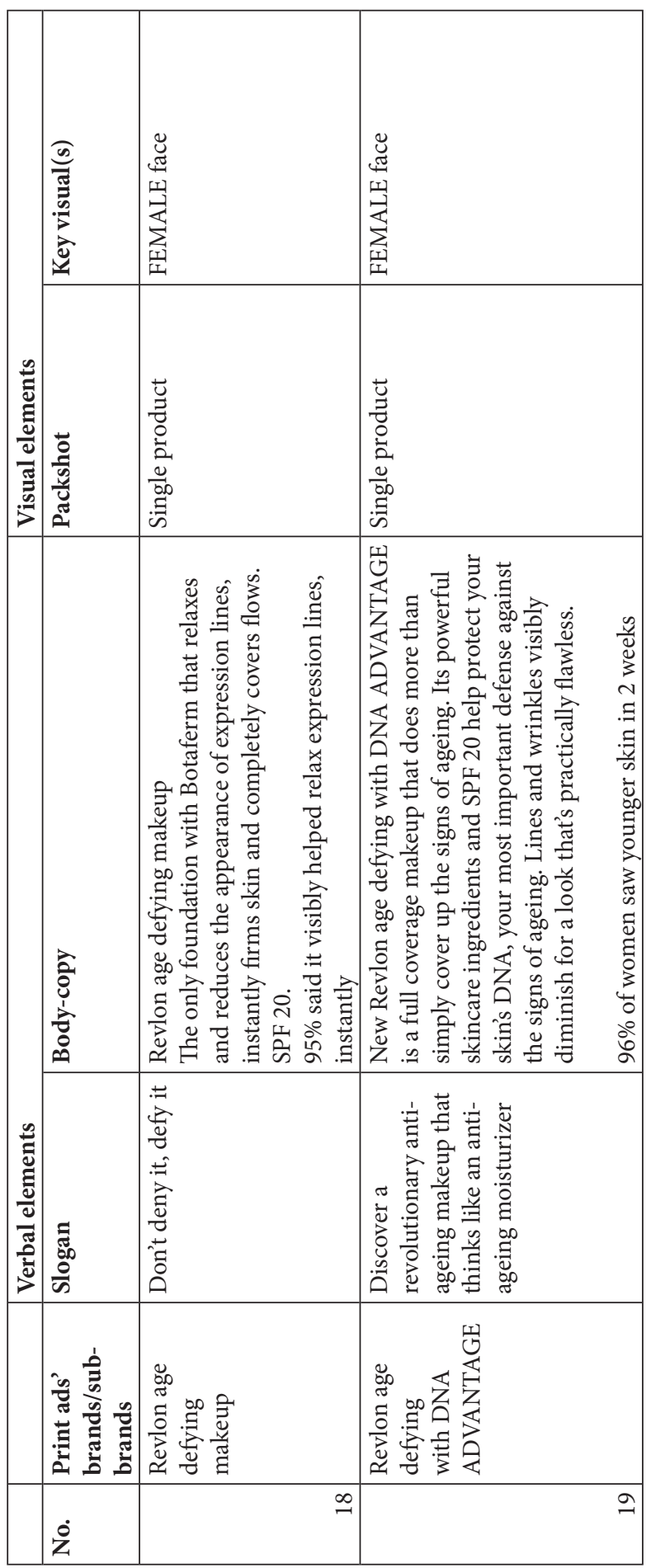


248 George Rossolatos

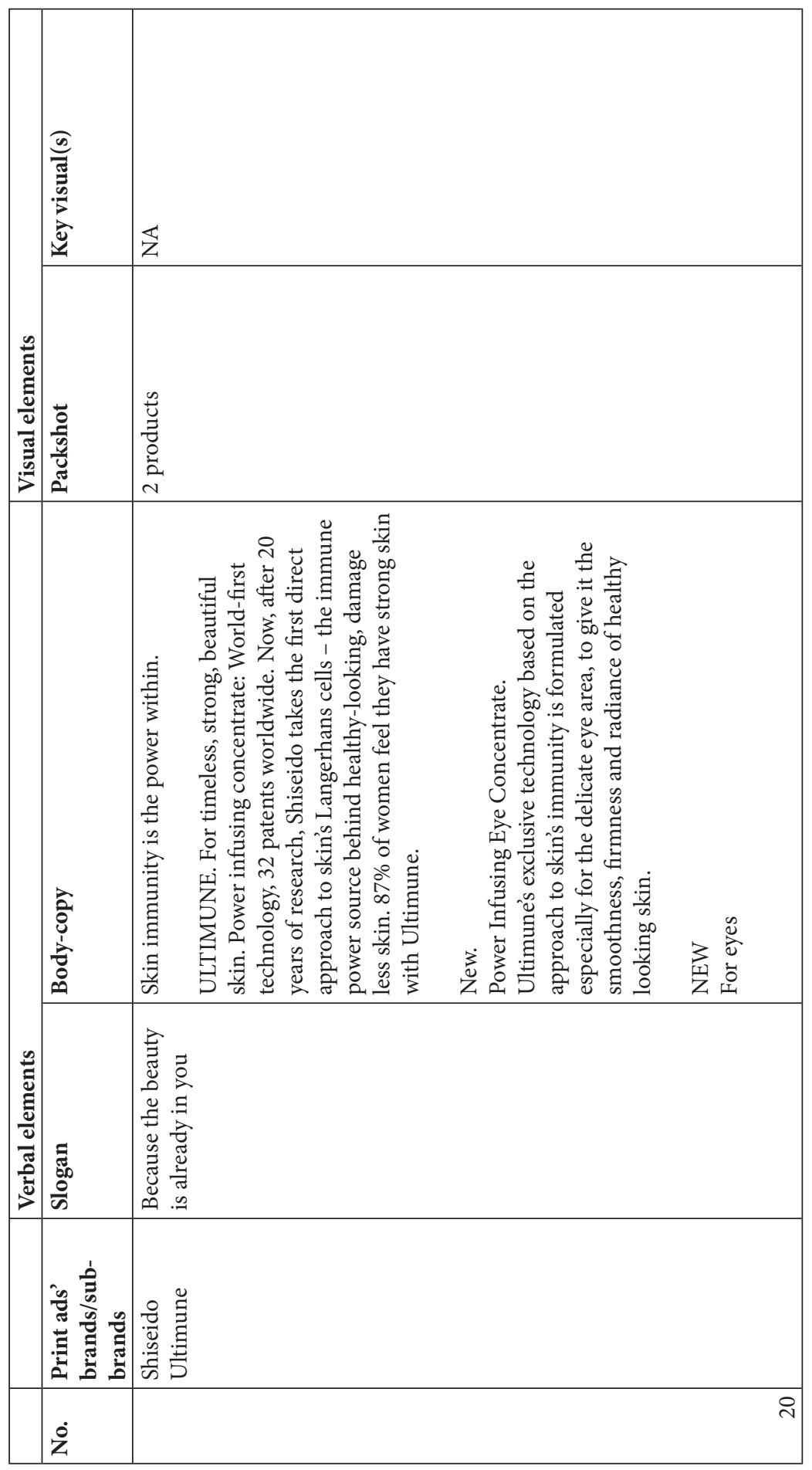




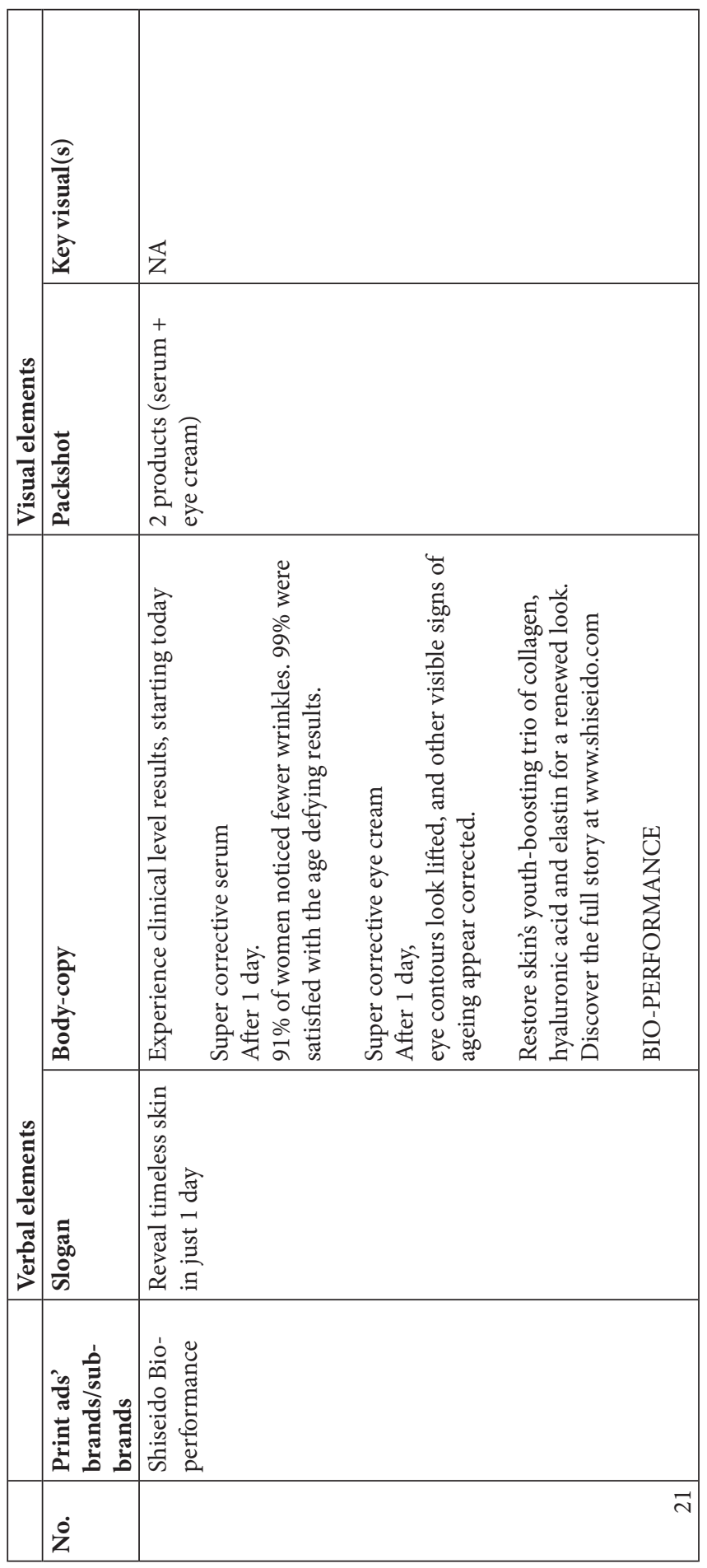




\section{References}

Abbott, Don P. 2006. Splendor and misery: Semiotics and the end of rhetoric. Rhetorica: A Journal of the History of Rhetoric 24(3): 303-323.

Armstrong, Scott J. 2010. Persuasive Advertising: Evidence-Based Principles. London: Palgrave. Barthes, Roland 1977. Image-Music-Text. London: Fontana.

Belk, Russell A. 2017. Qualitative research in advertising. Journal of Advertising 46(1): 36-47.

Betz, Gregory 2005. The vicious circle theorem - a graph-theoretical analysis of dialectical structures. Argumentation 19: 53-64.

Brooker, George 1981. A comparison of the persuasive effects of mild humor and mild fear appeals. Journal of Advertising 10(4): 29-40.

Carel, Havi 2006. Life and Death in Freud and Heidegger. New York: Rodopi.

Casalis, Matthieu 1975. The discourse of Penthouse: Rhetoric and ideology. Semiotica 15(4): 355-391.

Chang, Chun-Tuan 2011. Guilt appeals in cause-related marketing: The subversive roles of product type and donation magnitude. International Journal of Advertising 30(4): 587-616.

- 2012. Are guilt appeals a panacea in green advertising? The right formula of issue proximity and environmental consciousness. International Journal of Advertising 31(4): 741-771.

Charry, Karine M.; Demoulin, Nathalie T. M. 2012. Behavioural evidence for the effectiveness of threat appeals in the promotion of healthy food to children. International Journal of Advertising 31(4): 773-794.

Cline, Thomas W.; Kellaris, James J. 2007. The influence of humour strength and humour message relatedness on ad memorability: A dual process model. Journal of Advertising 36(1): 55-67.

Coupland, Justine 2009. Time, the body and the reversibility of ageing: Commodifying the decade. Ageing \& Society 2: 953-976.

Demske, James M. 1970. Being, Man \& Death. Kentucky: The University of Kentucky Press.

Dens, Nathalie; De Pelsmacker, Patrick; Janssens, Wim 2008. Exploring consumer reactions to incongruent mild disgust appeals. Journal of Marketing Communications 14(4): 249-269.

Dickinson, Sonia; Holmes, Matthew 2008. Understanding the emotional and coping responses of adolescent individuals exposed to threat appeals. International Journal of Advertising 27(2): 251-278.

Dickinson-Delaporte; Sonia J.; Holmes, Matthew D. 2011. Threat appeal communications: The interplay between health resistance and cognitive appraisal processes. Journal of Marketing Communications 17(2): 107-125.

Dyck, Ted 2002. Topos and enthymeme. Rhetorica: A Journal of the History of Rhetoric 20(2): 105-117.

Eco, Umberto 1986. Semiotics and the Philosophy of Language. Bloomington: Indiana University Press.

Ellison, Kirsten L. 2014. Age transcended: A semiotic and rhetorical analysis of the discourse of agelessness in North American anti-ageing skin care advertisements. Journal of Ageing Studies 29: 20-31.

Fairclough, Norman 1995. Critical Discourse Analysis: The Critical Study of Language. Essex: Longman. 
Ganceviciene, Ruta; Liakou, Aikaterini I.; Theodoridis, Athanasios; Makrantonaki, Evgenia; Zouboulis, Christos C. 2012. Skin anti-ageing strategies. Dermatoendocrinology 4(3): 308319.

Goddard, Angela 1998. The Language of Advertising. London: Routledge.

Greimas, Algirdas J. 1976. Maupassant: La sémiotique du Texte. Paris: Seuil.

Heidegger, Martin 2001. Being \& Time. Oxford: Blackwell.

Henthorne, Tony L.; LaTour, Michael S.; Nataraajan, Rajan 1993. Fear appeals in print advertising: An analysis of arousal and ad response. Journal of Advertising 20(2): 60-69.

Hornik, Jacob; Chezy Ofir; Rachamim, Matti 2017. Advertising appeals, moderators, and impact on persuasion: A quantitative assessment creates a hierarchy of appeals. Journal of Advertising Research 57(3): JAR-2017-017.

Johar, J. S.; Sirgy, Joseph 1991. Value-expressive versus utilitarian advertising appeals: When and why to use which appeal. Journal of Advertising 20(3): 24-33.

Kaur, Kuldip; Arumugam, Nalini; Mohamad, Norimah 2013. Beauty product advertisements: A critical discourse analysis. Asian Social Science 9(3): 61-71.

Killingsworth, Jimmie, M. 2005. Rhetorical appeals: A revision. Rhetoric Review 24(3): 249-263.

Klinkenberg, Jean-Marie 1990. Le Sens Rhétorique: Essais de Sémantique Litteraire. Toronto: Editions du Gref.

- 2008. La rhétorique dans la sémiotique: La composante créative du systeme. In: Klinkenberg, Jean-Marie; Badir, Sémir (eds.), Figures de la Figure: Sémiotique et Rhétorique Générale. Limoges: Presses Universitaires de Limoges, 35-56.

Latour, Michael S.; Snipes, Robin L.; Bliss, Sara J. 1996. Don't be afraid to use fear appeals: An experimental study. Journal of Advertising Research 36(2): 59-67.

Levi, Don S. 1985. The problem of the missing premise. Informal Logic 17(1): 67-88.

Levin, David Michael 1993. Decline and fall: Ocularcentrism in Heidegger's reading of the history of metaphysics. In: Levin, David Michael (ed.), Modernity and the Hegemony of Vision. California: University of California Press, 186-218.

Lotman, Mihhail 2009. Rhetoric: Semiotic approaches. In: Mey, Jacob L. (ed.), Concise Encyclopedia of Pragmatics. Tokyo: Elsevier, 582-589.

Macann, Christopher 1993. Four Phenomenological Philosophers: Husserl, Heidegger, Sartre, Merleau-Ponty. London: Routledge.

Machin, David; Mayr, Andrea 2012. How To Do Critical Discourse Analysis: A Multimodal Introduction. London: Sage.

Maciejewski, Jeffrey J. 2004. Is the use of sexual and fear appeals ethical? A moral evaluation by Generation Y college students. Journal of Current Issues and Research in Advertising 26(2): 97-105.

McQuarrie, Edward F.; Phillips, Barbara J. (eds.) 2008. Go Figure: New Directions in Advertising Rhetoric. New York: M. E. Sharpe.

Merleau-Ponty, Maurice 1968. The Visible and the Invisible. Evanston: Northwestern University Press.

Nöth, Winfried 1990. Handbook of Semiotics. Bloomington: Indiana University Press.

Okazaki, Shintaro; Mueller, Barbara; Taylor, Charles R. 2010. Measuring soft-sell versus hardsell advertising appeals. Journal of Advertising 39(2): 5-20.

O'Shaughnessy, John; O’Shaughnessy, Nicholas J. 2004. Persuasion in Advertising. New York: Routledge. 
Putrevu, Sanjay 2008. Consumer responses toward sexual and nonsexual appeals: The influence of involvement, need for cognition and gender. Journal of Advertising 37(2): 57-69.

Rastier, Francois 1987. Sémantique Interpretative. Paris: Presses Universitaires de France.

Reisigl, Martin 2014. Argumentation analysis and the discourse-historical approach: A methodological framework. In: Hart, Christopher; Cap, Piotr (eds.), Contemporary Critical Discourse Studies. New York: Bloomsbury, 67-96.

Richmond, David; Hartman, Timothy P. 1982. Sex appeal in advertising. Journal of Advertising Research 22(5): 53-61.

Ridling, Zaine 2001. The Lightness of Being: A Comprehensive Study of Heidegger's Thought. Kansas: Access Foundation.

Ringrow, Helen 2016. The Language of Cosmetics Advertising. London: Palgrave.

Rossolatos, George 2013a. On the pathology of the enthymeme: Accounting for hidden visual premises in advertising discourse. Signs and Society 2(1): 1-27.

- 2013b. A methodological framework for conducting multimodal rhetorical analyses of advertising films with ATLAS.ti. Proceedings of Atlas.ti User Conference: Fostering Dialogue on Qualitative Methods 2013, Berlin, Germany, 12-14 September 2013. Berlin: Digital Repository of Technische Universität Berlin.

- 2013c. Rhetorical transformations in multimodal advertising texts: From general to local degree zero. Hermes: Journal of Language and Communication in Business 50: 1-22.

- 2013d. An anatomy of the verbo-visual rhetorical landscape of the world's most valuable brands. International Journal of Marketing Semiotics 1: 73-125.

- 2013e. //rhetor.dixit//: Understanding Ad Texts' Rhetorical Structure for Differential Figurative Advantage. Amazon Press.

- 2014. Brand Equity Planning with Structuralist Rhetorical Semiotics. Kassel: Kassel University Press.

Ruiter, Robert A. C.; Abraham, Charles; Kok, Gerjo 2001. Scary warnings and rational precautions: A review of the psychology of fear appeals. Psychology \& Health 16: 613-630.

Ruiter, Robert A. C.; Kessels, Loes T. E.; Peters, Gjalt-Jorn Y.; Kok, Gerjo 2014. Sixty years of fear appeal research: Current state of the evidence. International Journal of Psychology 49(2): 63-70.

Sandywell, Barry 1999. Specular grammar: The visual rhetoric of modernity. In: Heywood, Ian; Sandywell, Barry (eds.), Interpreting Visual Culture: Explorations in the Hermeneutics of the Visual. London: Routledge, 31-58.

Sartre, Jean-Paul 1992. Being \& Nothingness. London: Routledge.

Slade, Christina 2002. Reasons to buy: The logic of advertisements. Argumentation 16: 157-178.

Snoeck Henkemans, Francisca 2000. State-of-the-art: The structure of argumentation. Argumentation 14: 447-473.

Tanner, Jeff 2006. Read this or die: A cognitive approach to an appeal to emotions. International Journal of Advertising 25(3): 414-416.

Toulmin, Stephen E. 2003. The Uses of Argument. Cambridge: Cambridge University Press.

Van Dijk, Teun 2006. Ideology and discourse analysis. Journal of Political Ideologies 11(2): 115-140.

Van Eemeren, Frans H.; Houtlosser, Peter 2000. Rhetorical analysis within a pragma-dialectical framework. Argumentation 14: 293-305.

Van Leeuwen, Theo 2008. New Tools for Critical Discourse Analysis. Oxford: Oxford University Press. 
Van Rees, M. Agnes 2013. Pragma-dialectical analysis and evaluation of problem-solving discussion. Argumentation 17: 465-479.

Walton, Douglas 1996. Practical reasoning and the structure of fear appeal arguments. Philosophy and Rhetoric 29(4): 301-313.

- 2000. Scare Tactics: Arguments that Appeal To Fear and Threats. London: Springer.

- 2006. Fundamentals of Critical Argumentation. Cambridge: Cambridge University Press.

Walton, Douglas; Reed, Chris; Macagno, Fabrizio 2008. Argumentation Schemes. Cambridge: Cambridge University Press.

Wicks, Jan LeBlanc; Warren, Ron; Fosu, Ignatius; Wicks, Robert H. 2009. Dual modality disclaimers, emotional appeals and production techniques in food advertising airing during programs rated for children. Is there a good balance? Journal of Advertising 38(4): 93-105.

Wilmoth, Gregory H. 1982. Changes in the discourse of Hustler: A study of rhetoric, vocabularies of motive, and ideology. Semiotica 39(3/4): 243-267.

Wodak, Ruth; Meyer, Michael 2001. Methods of Critical Discourse Analysis. London: Sage.

Zagar, Igor 2009. Topoi in critical discourse analysis. Šolsko Polje 5(6): 47-73.

Zompetti, Joseph P. 2006. The value of topoi. Argumentation 20:15-28.

\section{Донельзя приятная внешность: прагмаонтологический подход к раскрытию скрытой риторической структуры рекламного дискурса омоложения}

Цель настоящей статьи - определить аргументативные схемы и виды риторической конфигурации, которые составляют риторическую структуру дискурса печатных реклам омолаживающих косметических средств. Прагмаонтологический подход выдвинут как результат прагмадиалектической перспективы в риторическом анализе и критике. Прагмаонтологический подход добавляет интерпретативную глубину к открытой структуре аргументации, исходя из фундаментальной онтологии и экзистенциальной феноменологии. Анализ указывает на три уровня, на которых функционируют аргументы рекламного дискурса: явный уровень и два скрытых. На явном уровне рекламные объявления функционируют на фоне смешанных обращений этоса/пафоса/логоса, которые поддерживают схему ценностной аргументации. На основном скрытом уровне реклама, кажется, функционирует через косвенную апелляцию к страху, опираясь на схему аргументации последствий. На вторичном скрытом уровне реклама обращается косвенно к онтологической тоске, проявляя схему аргументации per impossible. Подчеркиваются культурные последствия рекламной политики омолаживания в ситуации, где ее призывы встречают суровую критику. 


\section{Võimatult hea välimus: Pragmaontoloogiline lähenemine vananemisvastase reklaamidiskursuse latentse retoorilise struktuuri kindlakstegemisele}

Käesoleva artikli eesmärgiks on teha kindlaks kõnetusviisid - argumentatiivsed skeemid ja retoorilise konfiguratsiooni laadid, millest koosneb vananemisvastaste nahahooldustoodete kategooria trükireklaamidiskursuse retooriline struktuur. Sel eesmärgil esitatake pragmaontoloogilist lähenemist retoorilises analüüsis ja kriitikas kasutatava pragmadialektilise perspektiivi tulemina. Pragmaontoloogiline lähenemine lisab vananemisvastaste toodete reklaamide eksplitsiitsesse argumenteerimisstruktuuri tõlgenduslikku sügavust, lähtudes fundamentaalsest ontoloogiast/eksistentsiaalsest fenomenoloogiast. Analüüs osutab kolmele tasandile, millel reklaamide argumendid toimivad - ühele avalikule ja kahele peidetud tasandile. Avalikul tasandil toimivad reklaamid eetose/paatose/logose kõnetusviiside taustal, mis toestavad väärtustest lähtuvat argumenteerimiskeemi. Esmasel peidetud tasandil tunduvad reklaamid toimivat kaudse hirmule apelleerimise kaudu, toetudes tagajärgedest lähtuvale argumenteerimisskeemile. Näidatakse, et teisasel peidetud tasandil apelleerivad reklaamid kaudselt ontoloogilisele ängistusele, kujutades endast argumentatsiooniskeemi per impossible. Poliitikaloome kultuurilisi implikatsioone rõhutatakse olukorras, kus vananemisvastaseid väiteid on tabamas tugev kriitika. 